\title{
Progesterone augments cell susceptibility to HIV-1 and HIV-1/HSV-2 co-infections
}

\author{
Viswanath Ragupathy', Wang Xue1, Ji Tan', Krishnakumar Devadas', Yamei Gao² \\ and Indira Hewlett1
}

'Lab of Molecular Virology, Division of Emerging Transfusion Transmitted Diseases, Center for Biologics Evaluation and Research, Food and Drug Administration, Silver Spring, Maryland, USA 2Division of Viral Products, Center for Biologics Evaluation and Research, Food and Drug Administration, Silver Spring, Maryland, USA
Correspondence should be addressed to V Ragupathy or I Hewlett Email

Viswanath.Ragupathy@fda. hhs.gov or Indira.hewlett@ fda.hhs.gov

\begin{abstract}
In human immunodeficiency virus type 1 (HIV-1)-infected women, oral or injectable progesterone containing contraceptive pills may enhance HIV-1 acquisition in vivo, and the mechanism by which this occurs is not fully understood. In developing countries, Herpes simplex virus type-2 (HSV-2) co-infection has been shown to be a risk for increase of HIV-1 acquisition and, if co-infected women use progesterone pills, infections may increase several fold. In this study, we used an in vitro cell culture system to study the effects of progesterone on HIV-1 replication and to explore the molecular mechanism of progesterone effects on infected cells. In our in vitro model, CEMss cells (lymphoblastoid cell line) were infected with either HIV-1 alone or co-infected with HSV-2. HIV-1 viral load was measured with and without sex hormone treatment. Progesterone-treated cells showed an increase in HIV-1 viral load $(1411.2 \mathrm{pg} / \mathrm{mL})$ compared with cells without progesterone treatment $(993.1 \mathrm{pg} / \mathrm{mL})$. Increased cell death was noted with HSV-2 co-infection and in progesterone-treated cells. Similar observations were noted in peripheral blood mononuclear cells (PBMC) cells derived from three female donors. Progesterone-treated cells also showed reduced antiviral efficacy. Inflammatory cytokines and associations with biomarkers of disease progression were explored. Progesterone upregulated inflammatory cytokines and chemokines conversely and downregulated anti-apoptotic $\mathrm{Bcl}-2$ expression. Nuclear protein analysis by electrophoretic mobility shift assay showed the association of progesterone with progesterone response element (PRE), which may lead to downregulation of $\mathrm{Bcl}-2$. These data indicate that progesterone treatment enhances HIV-1 replication in infected cells and co-infection with HSV-2 may further fuel this process.
\end{abstract}

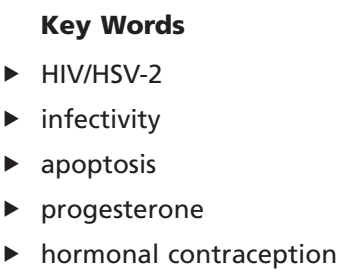

Journal of Molecular Endocrinology (2016) 57, 185-199

\section{Introduction}

Women account for one half of new HIV-1 infections worldwide (Joint United Nations Programme on HIV/AIDS 2013). The use of contraceptive pills by
() 2016 Society for Endocrinology Printed in Great Britain
HIV-1-seropositive women is considered to be important for preventing unintended pregnancies and reducing mother-to-child transmissions. Although these

Published by Bioscientifica Ltd 
hormones help to prevent unintended pregnancies, they also enhance HIV-1 acquisition (Ramjee \& Wand 2012, Morrison et al. 2015). Several epidemiological reports are inconsistent for progesterone-containing contraceptive use and risk of HIV-1 acquisition. A prospective study from seven African countries followed 2269 chronically HIV-1-infected women and showed no increased risk of HIV-1 disease progression for women on contraceptives compared with women who did not receive any contraceptive. In addition, this study observed no statistical difference in oral or injectable contraceptive use (Heffron et al. 2012, 2013). However, another study reported that injectable depot medroxyprogesterone acetate (DMPA) use had a moderate risk of HIV-1 acquisition, but not the oral hormonal contraception (Morrison et al. 2012). Based on these available data, in 2012, the World Health Organization released a technical statement noting that the data on hormonal contraceptives were inconclusive and recommending those women who are either at high risk or living with HIV-1 to continue the use of hormonal contraceptives. After the WHO report, several research studies indicated the risk associated with hormonal contraceptives. The study from South African population-based data on the use of hormonal contraceptive indicated a $12 \%$ increase in HIV-1 seroconversions after correcting for other HIV-1 risk variables (Ramjee \& Wand 2012). A pigtail model indicates higher susceptibility of HIV or SHIV during luteal phase (high progesterone levels) when macaques are intravaginally challenged with SHIV (Vishwanathan et al. 2011). Recently, a study on hormonal contraception and HIV acquisition reports individual patient data of several studies. Meta-analysis indicates that DMPA may increase HIV acquisition (controlling confounders and adjusted odds ratio of 1.5) compared with other methods of contraception (Morrison et al. 2015). In vitro studies on hormone effects support the clinical studies discussed earlier. A study showed progesterone decreased CCR5 expression and increased CXCR4 expression in PBMCs of HIV-uninfected and -infected patient samples cultured with progesterone suggesting progesterone may modulate HIV infection at receptor level (Cabrera-Munoz et al. 2012). We also observed in our previous in vitro study that progesterone augments replication and transmission of major HIV-1 subtypes (Ragupathy et al. 2013).

It has been shown that among HIV-1-infected women, HSV-2 co-infection is the most common sexually transmitted infection (STI). HSV-2 is the causative agent for genital herpes in humans and a major co-factor for HIV-1 acquisition (Wald \& Link 2002). HIV-1 and HSV-2 are considered to be synergistic pathogens, and genital herpes increases susceptibility to HIV-1. HIV-1 co-infection is known to affect HSV-2 shedding, reactivation rates and HSV-2 infectivity (Foss et al. 2011). In women, HSV-2 co-infection increases the risk of HIV-1 infection (Benjamin et al. 2008, Thurman \& Doncel 2012). The role of progesterone and HSV-2 co-infection was reported from a study from Kenya where both HSV-2 and oral contraceptives increase HIV-1 acquisition. In addition, contraceptive use and risk of HIV-1 acquisition are not associated with HSV-2 seropositivity (Baeten et al. 2007).

It is well known that susceptible cells infected with HIV-1 undergo apoptosis-mediated cell death. We had previously shown that an anti-apoptotic Bcl-2 family protein, $\mathrm{Bcl}-\mathrm{XL}$, and other proteins are able to decrease HIV-1 replication significantly suggesting that change in expression of this protein may affect HIV-1 replication in susceptible cells (Wang et al. 2010). Several other studies indicated that the $\mathrm{Bcl}-2$ molecule inhibits the normal apoptotic pathway to cell death and extends the life span of certain cells (Tsujimoto 1998, Czabotar et al. 2013). Similarly, HSV-2 can infect a variety of cell types, and productive infection is characterized by apoptosis and downregulation of Bcl-2 (Sciortino et al. 2006). Previous studies focusing the effects of progesterone on the female reproductive tract indicated that it regulates the activities of endometrial epithelial, stromal cells and spiral arteries to modulate blood flow during pregnancy (Perrot-Applanat et al. 1994). It has also been shown to exert immunomodulatory effects on T- and B-cells (Kyurkchiev et al. 2014). Studies on uterine leiomyoma tissues reported that Bcl-2 mRNA and protein levels might be regulated by progesterone (Yin et al. 2007). These studies indicate that progesterone levels affect the metabolism of cells. However, limited knowledge is available regarding the effects of progesterone on replication of pathogens.

In this study, we demonstrate that progesterone increases the replication of HIV-1 or HSV-2 by changing cellular proteins. Understanding the mechanisms behind progesterone use, HSV-2 co-infection and HIV-1 susceptibility and identifying new biomarkers that may be useful for assessing the risk of increased HIV-1 acquisition are important public health issues that may be critical for the development of successful HIV-1 prevention efforts.

Published by Bioscientifica Ltd. 


\section{Material and methods}

\section{Cells and viruses}

The T-cell line (lymphoblastoid leukemia cell) CEMss was obtained from NIH AIDS Reagent Program (Cat No: 776) and cultured in RPMI-1640 medium supplemented with $10 \%$ FBS (charcoal stripped), $2 \mathrm{mM}$ glutamine, $100 \mathrm{U} / \mathrm{mL}$ of penicillin and $100 \mathrm{U} / \mathrm{mL}$ streptomycin. Peripheral blood mononuclear cells (PBMC) from three HIV-1 seronegative female blood donors were isolated from buffy coat received from NIH Blood Bank. Before blood draw, informed consent was obtained from all of the healthy, normal blood donors according to the ethical principles of international ethical guidelines for biomedical research involving human subjects. We used our standard laboratory protocol for PBMC isolation from buffy coat (Zhang et al. 2008). Briefly, PBMCs were isolated by Ficoll/ Hypaque density-gradient centrifugation. Monocytes (>95\%) were removed by adherence to the culture flasks, and the remaining peripheral blood lymphocytes (PBL) were stimulated with $2 \mu \mathrm{g} / \mathrm{mL}$ PHA for 3 days to activate T-cells before infection. The PBL or PBMC was cultured in RPMI-1640 supplemented with 15\% FBS, 2 mM glutamine, $100 \mathrm{U} / \mathrm{mL}$ of penicillin, $100 \mathrm{U} / \mathrm{mL}$ of streptomycin and $5 \mathrm{U} / \mathrm{mL}$ of human interleukin-2 (Roche). Cell numbers were determined using Invitrogen Countess Automated Cell Counter, and cells stained with trypan blue were considered as dead cells.

The HIV-1IIIB strain was obtained from NIH AIDS Reagent Program and propagated in CEMss cells. HSV-2 strain MS was kindly contributed by Dr Jerry Weir, (FDA/CBER, Silver Spring, MD, USA) and propagated in the mammalian Vero cell line (derived from the kidney of a normal African green monkey) obtained from the American Type Culture Collection (ATCC). HSV-2 standard (Cat No: VR540D) for the TaqMan assay was purchased from ATCC. Serial dilutions were prepared in the ranges of $10-10^{5} \mathrm{pg} / \mathrm{mL}$ of dsDNA.

\section{Sex steroid hormones}

Two hours before infection, physiological levels of sex steroid hormones were added to cells. Steroid hormones were prepared as per manufacturer instructions, and the solvents were dried and diluted in the culture medium. For all hormone experiments, final concentrations are used as follows: progesterone (Sigma, P7556) 500 pM, $\beta$-estradiol (Sigma, E2257) 20 nM and testosterone (Sigma, T5411) $4 \mathrm{nM}$. No hormone controls has equal amount of either air-dried $100 \%$ ethanol (without $\mathrm{E}_{2}$ ) dissolved in culture medium or a culture medium (without $\mathrm{P}_{4}$ ). Further, hormone concentrations were maintained throughout the culture by supplementing hormonetreated media at each experimental time point after initial infection. However, hormones fluctuate in vivo or between the individuals which cannot be depicted in ex vivo studies. The focus here is to demonstrate the effects of selected physiological levels hormones on virus infection kinetics.

\section{Antivirals}

Antivirals AZT (3'-azido-2',3'-dideoxythymidine) (Cat; A7803) and Valacyclovir hydrochloride hydrate (Cat: V9889) were purchased from Sigma. For inhibition studies, we used AZT $\mathrm{IC}_{50} 5 \mu \mathrm{g} / \mathrm{mL}$ and valacyclovir $\mathrm{EC}_{50}$ $0.9 \mu \mathrm{g} / \mathrm{mL}$ of culture media.

\section{Antibodies and Western blot analysis}

Rabbit monoclonal antibodies against BCL2L1 (Clone E18) and CASP3 (Clone E87) were purchased from OriGene Technologies, Inc, Rockville, MD, USA. Western Blot analysis was carried out as described previously (Wang et al. 2012). After blocking, the blot was incubated for $2 \mathrm{~h}$ with $\mathrm{mAb}$ to rabbit BCL2L1 or CASP3 and horseradish peroxidase conjugated. Antibody binding was detected by chemiluminescence staining using the ECL detection kit (Amersham Biosciences).

\section{Experimental design}

CEMss cells are susceptible to infection with HIV-1 and HSV-2 as described previously (Legoff et al. 2007). These cells were seeded at $1 \times 10^{5} / \mathrm{mL}$ of culture medium in five $75 \mathrm{~mL}$ flasks. One flask served as the uninfected control, and the remaining four were infected with HIV-1 (5 or $10 \mathrm{ng} / \mathrm{mL}$ of HIV-1 p24) or HSV-2 (1 or 2 pfu/cell) or HIV-1 followed by HSV-2 or HSV-2 followed by HIV-1. Cells were infected for $4 \mathrm{~h}$ total at $37^{\circ} \mathrm{C}$ and $5 \% \mathrm{CO}_{2}$, washed and cultured. A total of $200 \mu \mathrm{L}$ culture supernatant were collected from each flask and marked as day 0. Similar set of experiments were performed for progesterone (hereafter called as $\mathrm{P}_{4}$ ), estradiol (hereafter called as $\mathrm{E}_{2}$ ), progesterone-estradiol mix (hereafter called as $\mathrm{E}_{2} / \mathrm{P}_{4}$ ) and testosterone hormone treatment. To monitor infectivity, $1 \mathrm{~mL}$ culture supernatant was collected at $4,7,14$ or 21 days after infection to measure HIV-1 p24 antigen levels or tested by a multiplex in-house HIV-1-1/HSV-2 TaqMan assay.

Published by Bioscientifica Ltd. 


\section{HIV-1 p24 determinations}

We used the Perkin-Elmer HIV-1 p24 Elisa Kit, Cat No: NEK050B001 for p24 measurements. All procedures were followed as per the manufacturer's instructions. Because p24 test kits were optimized for quantification in a narrow range of $200-12.5 \mathrm{pg} / \mathrm{mL}$, most of the culture supernatants were diluted in culture media to $1: 10,1: 100$ and 1:1000 before quantification.

\section{Real-time TaqMan}

Real-time quantitative PCR was performed on a 7500 Applied Biosystems Thermal Cycler in a $25 \mu \mathrm{L}$ reaction mix containing $1 \mu \mathrm{L}$ cDNA, $1 \times$ TaqMan QuantiTect Probe PCR Master Mix and 1X K15 or BAX or GAPDH assay. Thermal cycling was carried out at $50^{\circ} \mathrm{C}$ for $2 \mathrm{~min}, 95^{\circ} \mathrm{C}$ for $10 \mathrm{~min}$, followed by 40 cycles at $95^{\circ} \mathrm{C}$ for $15 \mathrm{~s}$, and $60^{\circ} \mathrm{C}$ for $1 \mathrm{~min}$. All samples were run in duplicate. To determine the viral load of the two viruses in a single assay, we developed a multiplex quantitative TaqMan assay. For standard curve, HIV-1 (Cat No: 3443) was obtained from NIH AIDS Reagent and HSV-2 (Cat. No: VR-540D) from ATCC. Our multiplex TaqMan PCR was designed using the following primers and probes HSV-2 and HIV-1. Primers for HIV-1 included: (114bp) gag gene F-ACCCATGTTTACAGCATTATCAGAAG, R-GCTTGATGTCCCCCTACTGTATTT; probe FAM, AGCC-ACCCCACAAGATCTAAACACCATGT-MGB; for HSV-2 (118bp), HSV-2 (333) glycoprotein B gene Acc. No: M15118, F-TGCAGTTTACGTATAACCACATACAGCRAGCTTGCGGGCCTCGTT; VIC-CGCCCCAGCATGTCG TTCACGT-MGB. The formula for measuring the concentration of HSV-2 DNA is $6.02 \times 10^{23}$ (copies $\left./ \mathrm{mol}\right) \times$ A260 $(\mathrm{ng} / \mathrm{mL}) /(\mathrm{DNA}$ length $\times 650)=$ copies $/ \mathrm{mL}$. With several repeated experiments, we optimized the assay conditions to quantify both these viruses through derivation of a standard graph.

\section{PCR arrays}

RNA was prepared from cell pellets using the RNeasy Mini Kit (Cat: 74104) from Qiagen after homogenization. The RNA samples were DNase I (Roche Laboratories) treated and further purified on a column from an RNeasy kit (Qiagen). Reverse transcription was carried out using a QIAGEN RT2 first-strand kit (Cat No: 330401) using $1 \mu \mathrm{g}$ RNA. The inflammatory cytokine-chemokine 'RT2 profiler array' from SA Biosciences was used to measure the transcript levels of various cytokines. The array contains primer sets for 84 cytokines/chemokines
(PAHS-011A-24) and appropriate housekeeping controls. We also performed similar analysis for HIV-1 infection and host responses (PAHS-012A). Real-time PCR was carried out as described by the manufacturer, using an Applied Biosystems T7500 Thermal Cycler.

The mRNA expression level for each gene was normalized using the expression of HPRT as a control housekeeping gene and compared with the data obtained with the negative control (RNA from uninfected cells) according to the $2^{-\Delta \Delta c t}$ method (Livak \& Schmittgen 2001). Results were considered significant when relative mRNA expression was twofold higher or lower than that of the uninfected cells. The results were confirmed by quantitative real-time PCR on individual RNA samples using the QuantiTect SYBR Green PCR Kit (Qiagen) and the same sets of primers as used in the PCR cytokine array (S A Bioscience Corporation, Frederick, MD, USA).

\section{Electrophoretic mobility shift assay}

CEMss cells were treated for $2 \mathrm{~h}$ with $\mathrm{P}_{4}$ as indicated earlier. Nuclear protein was extracted from whole cells using NE-PER nuclear and cytoplasmic extraction reagents (Pierce). EMSA was performed using a LightShift Chemiluminescent EMSA kit (Pierce). In EMSA, we used previously published (Yin et al. 2007) sequence of the double-stranded oligonucleotide 5-GACAGAGGATCATGCTGTACTTAAA-3, which is identical to the 25-bp-long sequence (-559/-535bp) within the promoter region of the Bcl-2 gene. This sequence contains an imperfect 15-bp palindromic PRE $(553 / 539)$. The mutant probe is an unlabeled 25-bp oligonucleotide, in which $3 \mathrm{bp}$ of the 15-bp PRE at $-549,-543$ and -540 positions were replaced by As (GACAAAGGATAATACTGTACTTAAA). Biotin endlabeled oligonucleotide probes were synthesized from the CBER core facility and annealed to the complementary oligonucleotides. Hundred pico moles labeled probe and $5 \mu \mathrm{g}$ nuclear extract were incubated for $20 \mathrm{~min}$ at room temperature in a reaction mix containing 5\% ( $\mathrm{vol} / \mathrm{vol})$ glycerol, $10 \mathrm{mM}$ Tris- $\mathrm{HCl}, 50 \mathrm{mM} \mathrm{NaCl}, 1 \mathrm{~mm} \mathrm{MgCl}_{2}$, $0.5 \mathrm{~mm}$ dithiothreitol and $2 \mathrm{~g}$ poly (dI-dC). For the EMSA, unlabeled wild-type or mutant probe ( $4 \mathrm{pmol})$ was added simultaneously with the labeled probe. Nondenaturing polyacrylamide gels (5\%) were used to resolve proteinDNA complexes. Protein-DNA samples were transferred to the Biodyne B precut modified nylon membrane (Pierce). Protein-DNA complexes were detected using a LightShift Chemiluminescent EMSA Kit (Pierce) and exposed to the CL-XPosure film (Pierce).

Published by Bioscientifica Ltd 


\section{Statistical analysis}

The statistical module Prism, version 5.0 (GraphPad Software) was used to perform unpaired two-tailed Student's t-test with group sizes of two or analysis of variance (ANOVA) with Bonferroni post hoc $t$-test for greater than two group sizes.

\section{Results}

\section{Infectivity of HIV-1 and HSV-2 and multiplex TaqMan}

To determine the HIV-1 viral load from CEMss cells in the presence of hormone or HSV-2, cells were exposed to HIV-1 (10 ng p24/mL) and HSV (2 pfu) either alone or together. Two hours before infection, an aliquot of cells were exposed to physiological levels of hormone also. HIV-1 viral load quantification was carried out using two different assays, the HIV-1 p24 Ag ELISA and Real-time TaqMan Assay. At 7 d.p.i (days post infection) the means of HIV-1 p24 levels were higher (Fig. 1A) for cells treated with $\mathrm{E}_{2}(1229.1 \mathrm{pg} / \mathrm{mL})$ and significantly $(P<0.05)$ higher $\mathrm{P}_{4}$ $(1411.2 \mathrm{pg} / \mathrm{mL})$ relative to $\mathrm{NH}(993.1 \mathrm{pg} / \mathrm{mL})$. However, no significant differences were noted for cultures treated with $\mathrm{E}_{2} / \mathrm{P}_{4} \operatorname{mix}(1076.7 \mathrm{pg} / \mathrm{mL})$ and testosterone $(876.5 \mathrm{pg} / \mathrm{mL})$. HSV-2 co-infection commonly occurs with HIV-1 and shares the same sexual route of transmission. We investigated when the HSV-2-infected cells were superinfected with HIV-1 and measured the HIV-1 viral load at 7 d.p.i. HIV-1 p24 level means were significantly $(P<0.05)$ lower (Fig. 1A) for cells treated with $\mathrm{E}_{2}$ (508 pg/mL), $\quad \mathrm{E}_{2} / \mathrm{P}_{4} \quad \operatorname{mix} \quad(346.8 \mathrm{pg} / \mathrm{mL})$, testosterone $(350.5 \mathrm{pg} / \mathrm{mL})$ and very significantly lower $(P<0.01)$ for $\mathrm{P}_{4}$ $(190.9 \mathrm{pg} / \mathrm{mL})$, relative to $\mathrm{NH}(770.4 \mathrm{pg} / \mathrm{mL})$.

In this study, we used two virus types; to quantify both these viruses simultaneously, we used multiplex TaqMan Assay. Nucleic acids were extracted from culture supernatants to quantify both HIV-1 and HSV-2. Like HIV-1 p24 assay, similar trend was observed with TaqMan Assay although TaqMan is not true measure of infectivity. At 7 d.p.i increased levels of HIV-1 RNA (Fig. 1B) for cells treated with $\mathrm{E}_{2}\left(2.81 \log _{10} \mathrm{cps} / \mathrm{mL}\right), \mathrm{P}_{4}\left(3.22 \log _{10} \mathrm{cps} / \mathrm{mL}\right)$, $\mathrm{E}_{2} / \mathrm{P}_{4} \operatorname{mix}\left(3.06 \log _{10} \mathrm{cps} / \mathrm{mL}\right)$ and testosterone $\left(2.78 \log _{10}\right.$ cps/mL) relative to $\mathrm{NH}\left(2.72 \log _{10} \mathrm{cps} / \mathrm{mL}\right)$. Although no significant differences were noted for $\mathrm{E}_{2}$ and testosterone, $\mathrm{P}_{4}$ viral load was significantly higher $(P<0.05)$. In HSV-2 co-infection, HIV-1 viral load was lower (Fig. 1B) for cells treated with $\mathrm{P}_{4}\left(1.86 \log _{10} \mathrm{cps} / \mathrm{mL}\right), \mathrm{E}_{2} / \mathrm{P}_{4} \operatorname{mix}\left(2.39 \log _{10}\right.$ $\mathrm{cps} / \mathrm{mL})$ and testosterone $\left(2.38 \log _{10} \mathrm{cps} / \mathrm{mL}\right)$ relative to $\mathrm{NH}$ (2.66 $\log _{10} \mathrm{cps} / \mathrm{mL}$ ). However, for $\mathrm{E}_{2}\left(2.50 \log _{10} \mathrm{cps} / \mathrm{mL}\right)$, no difference in viral load was noted in comparison with $\mathrm{NH}$.
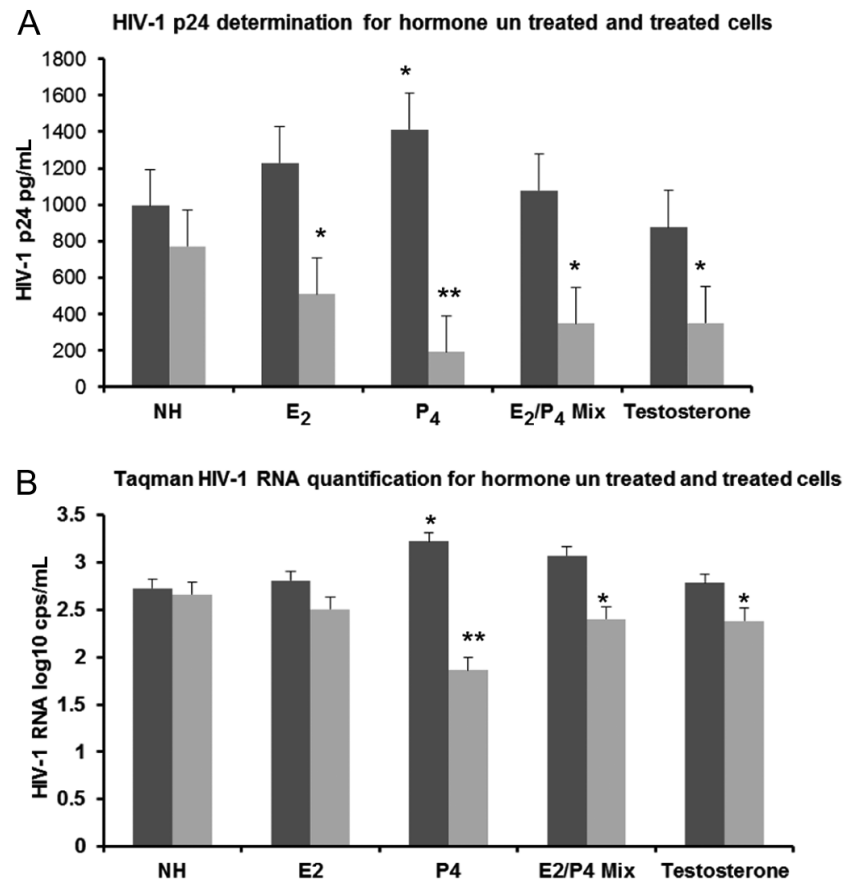

Figure 1

HIV-1 viral load determination by a quantitative p24 ELISA and TaqMan Assay. Comparisons of two virus quantification measurements. Cells were infected with HIV (dark bar) or co-infected with HSV (light bar), and culture supernatant collected at 7 d.p.i. for viral load measurements. Infected cells were either not hormone treatment $(\mathrm{NH})$ or treated with hormones estradiol $\left(E_{2}\right)$, progesterone $\left(P_{4}\right)$, a mix of estradiol with progesterone $\left(E_{2} / P_{4} M i x\right)$ and testosterone. Statistical significance was derived by comparing $\mathrm{NH}$ with hormone-treated groups. (A) Measurement of HIV-1 by quantitative enzyme immuno p24 assay. HIV-1 viral loads of cells treated with different hormone types were compared with cells treated with no hormone. Although differences in HIV viral load noted comparing $\mathrm{NH}$ with hormone treatment only $\mathrm{P}_{4}$ treatment had significantly $\left({ }^{*} P<0.05\right)$ higher viral load. Similar experiments were repeated for HSV-2/HIV-1 co-infected cells. Significant $(* P<0.05)$ low viral load was noted for hormone-treated groups and very significant $(* * P<0.01)$ reduction in viral load was noted for $P_{4}$-treated group. But for $E_{2}$-treated cells, there were no significant differences in viral load when compared with $\mathrm{NH}$. (B) Measurement of HIV-1 by quantitative TaqMan assay indicating similar trends of viral load differences for $P_{4^{-}}$and $E_{2} / P_{4}$ mix-treated cells with HIV or HSV-2/HIV-1 co-infection. However, no statistical significance noted for HIV-infected cells treated with $E_{2}$ or testosterone. In co-infected cells, $\mathrm{P}_{4}(* * P<0.01)$, mix and testosterone treatment showed significant $(* P<0.05)$ viral load differences. No significant differences were noted for $\mathrm{E}_{2}$ compared with $\mathrm{NH}$. The error bars represent standard errors of the means (S.E.M.) for triplicate measurements of at least three experiments.

Once we determined that viral load was quantifiable with or without hormone treatment using multiplex TaqMan, we focused on specifically quantifying each of these viruses in the presence and absence of hormones. In addition, due to assay limitations and high viral load at day 7 , in rest of the long-term experiments, virus infectivity dose was reduced to half for optimal quantifications.

Published by Bioscientifica Ltd. 


\section{Effects of hormone-treated cells and virus replication}

Cells exposed to HIV-1 and HSV-2 was cultured up to 14 days, and viral load was quantified at two intervals to study the hormone effects on replication kinetics. HIV-1 viral load in terms of RNA cps/mL were represented in $\log _{10}$ values. Although two time points were measured, infectivity was delayed for certain culture conditions; hence, data were shown only for measurements at day 14. As noted earlier, HIV-1 RNA cps/mL means were significantly higher (Fig. $2 \mathrm{~A})$ at 14 d.p.i $(P<0.01)$ for cells treated with $\mathrm{E}_{2}\left(3.9 \log _{10} \mathrm{cps} / \mathrm{mL}\right), \mathrm{P}_{4}\left(3.61 \log _{10} \mathrm{cps} / \mathrm{mL}\right)$, $\mathrm{E}_{2} / \mathrm{P}_{4} \operatorname{mix}\left(3.52 \log _{10} \mathrm{cps} / \mathrm{mL}\right)$ and testosterone $\left(3.51 \log _{10}\right.$ cps $/ \mathrm{mL})$ relative to $\mathrm{NH}\left(2.39 \log _{10} \mathrm{cps} / \mathrm{mL}\right)$. Similarly, HSV-2 DNA level means were significantly higher $(P<0.05)$ (Fig. 2B) for cells treated with $\mathrm{E}_{2}\left(12.24 \log _{10} \mathrm{cps} / \mathrm{mL}\right)$, $\mathrm{E}_{2} / \mathrm{P}_{4} \operatorname{mix}\left(12.41 \log _{10} \mathrm{cps} / \mathrm{mL}\right)$ and nonsignificant levels for $\mathrm{P}_{4}(11.1 \log 10 \mathrm{cps} / \mathrm{mL})$ and testosterone (10.76 $\left.\log _{10} \mathrm{cps} / \mathrm{mL}\right)$ relative to $\mathrm{NH}\left(10.74 \log _{10} \mathrm{cps} / \mathrm{mL}\right)$.

Next, we performed co-infection studies with HIV-1 infection followed by HSV-2 or vice versa to determine which co-infection augments the pathogenesis of HIV-1. The experiments were performed with and without hormone treatment to study viral replication kinetics.

As described earlier, the mean HIV-1 RNA was significantly higher (Fig. 2C) at 14d.p.i $(P<0.05)$ with $\mathrm{P}_{4}$ (3.42 $\left.\log _{10} \mathrm{cps} / \mathrm{mL}\right), \mathrm{E}_{2} / \mathrm{P}_{4} \operatorname{mix}\left(3.57 \log _{10} \mathrm{cps} / \mathrm{mL}\right.$ ) and testosterone $\left(3.47 \log _{10} \mathrm{cps} / \mathrm{mL}\right)$ relative to $\mathrm{NH}\left(2.47 \log _{10}\right.$ cps/mL) but nonsignificant with $\mathrm{E}_{2}\left(2.85 \log _{10} \mathrm{pg} / \mathrm{mL}\right)$. When HIV-1 infected cells were superinfected with HSV-2, HIV-1 viral load was significantly higher (Fig. 2D) for $\mathrm{E}_{2}\left(3.66 \log _{10} \mathrm{cps} / \mathrm{mL}\right), \mathrm{P}_{4}\left(3.68 \log _{10} \mathrm{cps} / \mathrm{mL}\right), \mathrm{E}_{2} / \mathrm{P}_{4} \mathrm{mix}$ (3.45 $\left.\log _{10} \mathrm{cps} / \mathrm{mL}\right)$ and testosterone $\left(3.45 \log _{10} \mathrm{cps} / \mathrm{mL}\right.$ ) relative to $\mathrm{NH}\left(2.23 \log _{10} \mathrm{cps} / \mathrm{mL}\right)$. It was observed that there were no significant differences $(P>0.05 ; 0.93)$ in HIV-1 viral load in cells infected with HSV-2 first and later infected with HIV-1 or vice versa. HIV-1 RNA was little higher $\left(2.74 \log _{10} \mathrm{cps} / \mathrm{mL}\right)$ in HIV-1 superinfection of HSV-2-infected cells relative to $\mathrm{NH}\left(2.39 \log _{10} \mathrm{cps} / \mathrm{mL}\right)$. In all subsequent co-infection experiments, cells were first infected with HSV-2 followed by HIV-1. In co-infected cells treated with $\mathrm{P}_{4}$, mean HIV-1 viral load (3.68 $\left.\log _{10} \mathrm{pg} / \mathrm{mL}\right)$
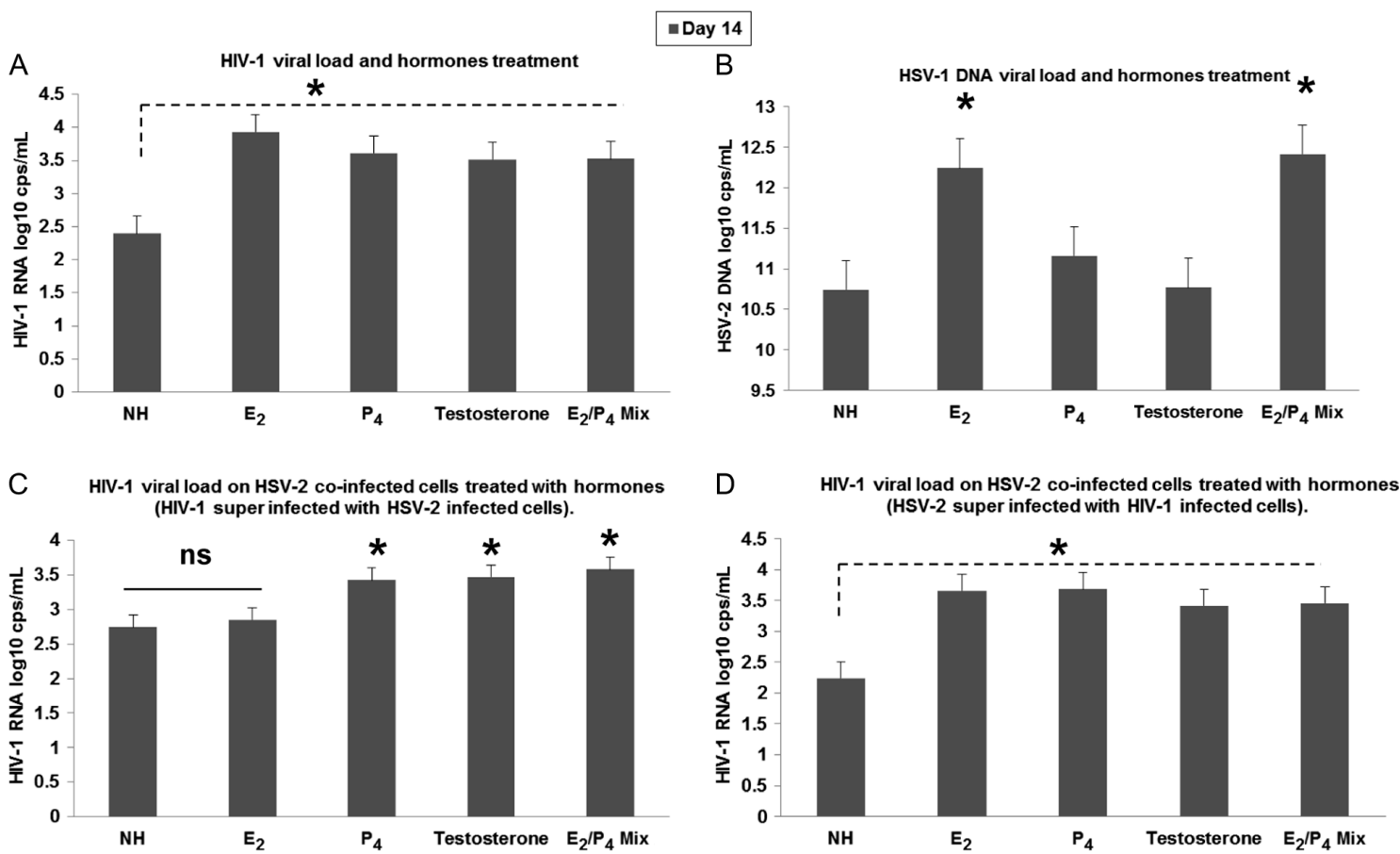

Figure 2

Screening of hormone effects on HIV-1 or HSV-2 replication kinetics. (A) Virus infection of cells and hormone treatment are similar to Fig. 1. At 7 d.p.i, no significant HIV-1 viral load changes were noted and hence not presented here. Bar chart indicates viral replication with and without hormone treatment measured at 14 d.p.i. Error bars represent standard errors of the means (S.E.M.). Significance was evaluated by two-way analysis of variance (ANOVA) with Bonferroni posttests. ${ }^{*} P<0.05$. (B) Similarly, cells were infected with $\mathrm{HSV}-2$ virus, and its replication was measured and compared for hormone-treated and -untreated cells. HSV-2 replication was significantly $(P<0.05)$ higher at 14 d.p.i in cells treated with $E_{2}$ or $E_{2} / P_{4}$ mix but nonsignificant with $\mathrm{P}_{4}$ or testosterone. (C) Cells were first infected with HSV-2 (2h) and co-infected with HIV-1 (2h) or vice versa (D). In (C) compared with cells treated with no hormone, significant $(P<0.05)$ increase in HIV-1 titer was seen with cells treated with $\mathrm{P}_{4}$, testosterone and $\mathrm{E}_{2} / \mathrm{P}_{4}$ mix but nonsignificant (ns) for $E_{2}$-treated cells. (D) All hormone-treated cells had significant increase $(P<0.01)$ of HIV-1 viral load compared with $\mathrm{NH}$.

http://jme.endocrinology-journals.org DOI: 10.1530/JME-16-0138
(C) 2016 Society for Endocrinology Printed in Great Britain
Published by Bioscientifica Ltd 


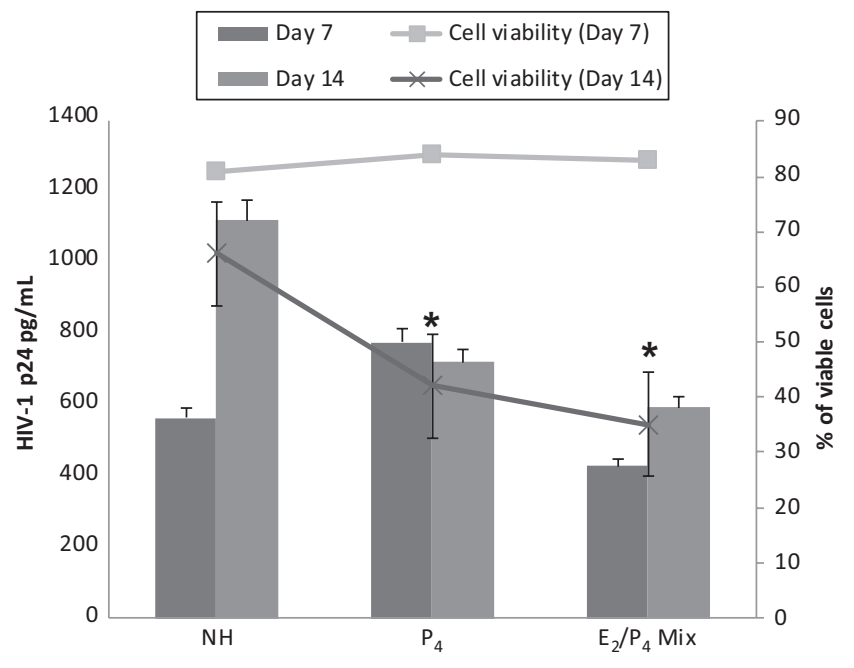

Figure 3

HIV-1 p24 levels were measured in cells untreated $(\mathrm{NH})$ or treated with $\mathrm{P}_{4}$ or $E_{2} / P_{4}$ mix and compared with cell viability. These cells were co-infected with HSV-2, and experiments were performed at similar conditions. HIV-1 virus titer was measured at two time points, days 7 and 14, and data are shown as bar graph (primary axis). Cell viability (trypan dye exclusion) was measured using automated cell counter and plotted as percentages (in right y-axis). At day $7,>80 \%$ of cells were viable in untreated or hormone-treated cells, whereas HIV-1 viral load was little higher in $\mathrm{P}_{4}$-treated cells $(802 \mathrm{pg} / \mathrm{mL})$ compared with $\mathrm{NH}(525 \mathrm{pg} / \mathrm{mL})$ or $E_{2} / P_{4}(410 \mathrm{pg} / \mathrm{mL})$ mix. At day 14 , spontaneous loss of viable cells was observed $(P<0.05)$ with $\mathrm{P}_{4^{-}}$and $\mathrm{E}_{2} / \mathrm{P}_{4}$ mix-treated cells (line graph) and no significant rise in HIV-1 p24 levels (bar graph). Results shown are the mean (S.E.M.) from three different replicates of at least three experiments.

at day 14 was relatively higher compared with $\mathrm{NH}$ (2.74 $\left.\log _{10} \mathrm{pg} / \mathrm{mL}\right)$. In addition, co-infection experiments with $\mathrm{P}_{4}$-treated cultures showed extensive cell death.

We further analyzed the effects of $\mathrm{P}_{4}$ either alone or in combination with estradiol and simultaneously measured the cell viability. Analysis was performed for two time points, day 7 and 14. At day 7, the mean HIV-1 p24 of $\mathrm{NH}$ was $563.2 \mathrm{pg} / \mathrm{mL}, \mathrm{P}_{4}, 776 \mathrm{pg} / \mathrm{mL} ; \mathrm{E}_{2} / \mathrm{P}_{4}$ mix, $427 \mathrm{pg} / \mathrm{mL}$ and cell viability for each experimental condition was 81-84\% (Fig. 3). At day 14, mean HIV-1 p24 of $\mathrm{NH}$ was $1119.5 \mathrm{pg} / \mathrm{mL}, \mathrm{P}_{4}, 721 \mathrm{pg} / \mathrm{mL} ; \mathrm{E}_{2} / \mathrm{P}_{4} \mathrm{mix}$, $593 \mathrm{pg} / \mathrm{mL}$ and cell viability was significantly $(P<0.05)$ lower for $\mathrm{P}_{4}(42 \%)$ and $\mathrm{E}_{2} / \mathrm{P}_{4}$ mix (35\%) than for NH $(66 \%)$.

Next, we determined the cell viability using an automated cell counter at three different time points of multiple experimental conditions (Fig. 4). Equal numbers of cells were either infected with HIV-1 or HSV-2 or uninfected and treated with $\mathrm{P}_{4}$ alone or together with estradiol. At days 7 and 9, cell viability was 80-92\% in all experimental conditions. However, at day 14, the viability dropped to $35-88 \%$ and more specifically HSV-2/HIV-1 cultures treated with $\mathrm{P}_{4}$ had significantly $(P<0.05)$ lower percent of viable cells compared with uninfected $\mathrm{P}_{4}$-treated cells. The extensive cell death of cultures with co-infection and $\mathrm{P}_{4}$ treatment may likely be due to the involvement of cellular factors.

\section{Reduced efficacy of antivirals for virus-infected cells treated with $\mathrm{P}_{4}$}

We further determined the effect of treatment with antivirals on $\mathrm{P}_{4}$-exposed cells infected with HIV-1 or HSV-2/HIV-1. Infected cells were cultured with and without $\mathrm{P}_{4}$ treatment for 7 days, and a subset of cells were treated with AZT for HIV-1 and AZT/Valacyclovir for co-infections of HSV-2/HIV-1. The baseline HIV-1 viral load (without ARVs) at day 7 was $0.21 \mathrm{ng} / \mathrm{mL}$ for $\mathrm{P}_{4}$-untreated cells and $0.27 \mathrm{ng} / \mathrm{mL}$ of p24 for $\mathrm{P}_{4}$-treated cells and in co-infection, $0.55 \mathrm{ng} / \mathrm{mL}$ for cells not treated with $\mathrm{P}_{4}$ and $0.645 \mathrm{ng} / \mathrm{mL}$ of $\mathrm{p} 24$ for $\mathrm{P}_{4}$-treated cells confirming that there was productive HIV-1 infection.

The cultures were split into two for antiviral treatment and no treatment. The HIV-1 p24 levels for AZT-treated cultures had significantly lower HIV-1 p24 levels (means of: day $10=0.29$; day $14=0.29$; day $21=0.48 \mathrm{ng} / \mathrm{mL}$ ) than cultures without AZT (means of HIV-1 p24: day $10=0.29$; day $14=2.48$; day $21=5.92 \mathrm{ng} /$ $\mathrm{mL}$ ) (Fig. 5A). When similar experiments were repeated for $\mathrm{P}_{4}$-treated cells (Fig. 5A), HIV-1 viral load was 5-fold higher $(P<0.01)$ at day $21(29.3 \mathrm{ng} / \mathrm{mL}$ of $\mathrm{p} 24)$ compared

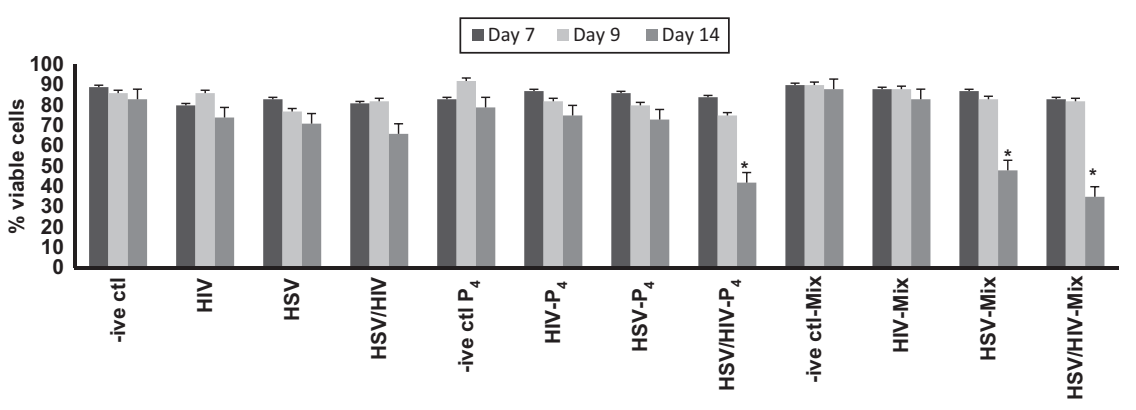

Figure 4

Cell viability under different experimental conditions. Cells were either uninfected (negative control) or infected and hormones treated as indicated. Cells viability (trypan dye exclusion) was measured at three time points, day 7,9 and 14 using automated cell counter. Significant cell death $(P<0.05)$ was noted with $\mathrm{P}_{4}$-treated cells and co-infected with HSV/HIV. Error bars represent the standard errors of the means, and asterisks indicate cells that are significantly low viable cells as determined by ANOVA. 

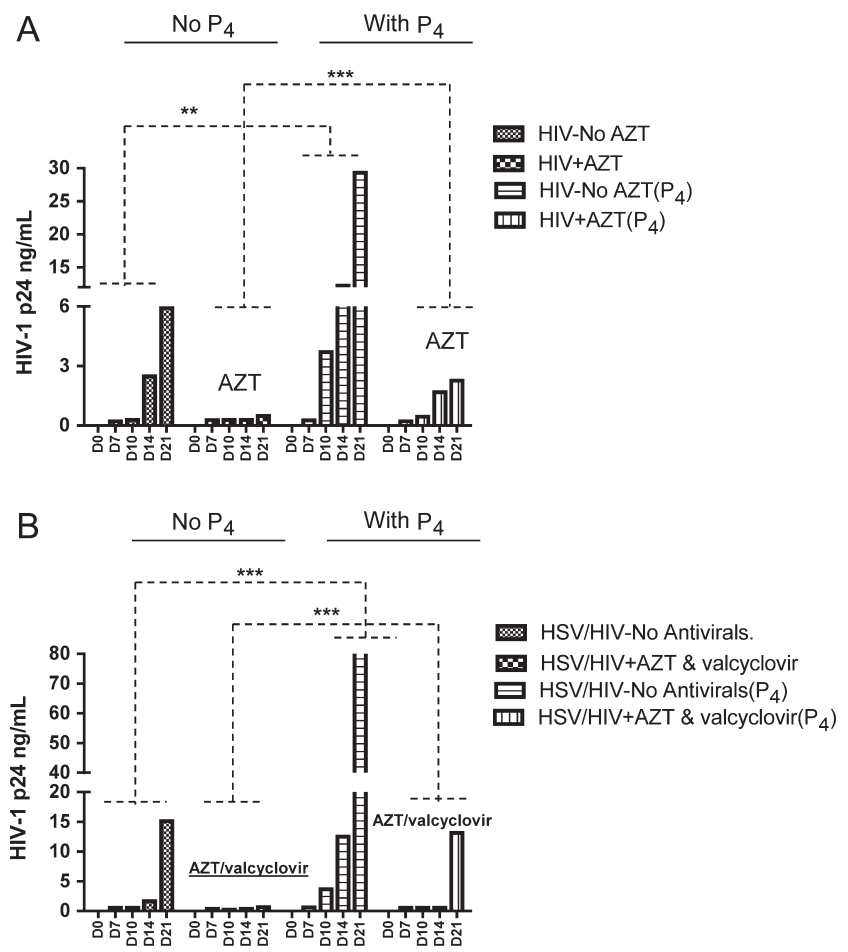

Figure 5

Progesterone effects on antiviral efficacy. (A) HIV-1-infected cells were cultured with and without $\mathrm{P}_{4}$ for 21 days. Similarly, another $\mathrm{P}_{4}$-treated HIV-infected cells are cultured in the presence of HIV-1 replication inhibitor AZT. In both, HIV titer was measured at day zero to day 21 (5 intervals) using PerkinElmer Quantitative Enzyme Immuno p24 Assay. At each time point, three replicates were measured and means were plotted in the bar graph. $\mathrm{P}_{4}$-treated cells had significant $(P<0.01)$ higher viral load compared with $\mathrm{P}_{4}$-untreated cells. AZT inhibits HIV replication in the absence of $\mathrm{P}_{4}$ but significantly $\left({ }^{* * *} P<0.001\right)$ increased virus titer as observed in $\mathrm{P}_{4}$-treated cells. (B) Similar experimental conditions of (A) were repeated for HSV/HIV co-infections. For inhibition studies in addition to AZT, valacyclovir (to inhibit HSV-2) was used. Similar trend was observed. $P_{4}$-treated cells had significantly $\left({ }^{* * *} P<0.001\right)$ higher viral load compared with no $\mathrm{P}_{4}$ cells. AZT and valacyclovir inhibit HIV/HSV-2 replication in no $P_{4}$, but significantly $\left({ }^{* * *} P<0.001\right)$ increased virus titer observed in $\mathrm{P}_{4}$-treated cells.

with that of cultures without $\mathrm{P}_{4}(5.92 \mathrm{ng} / \mathrm{mL}$ of $\mathrm{p} 24)$. In addition, HIV-1 p24 levels did not decrease completely with AZT treatment (day $10=0.44$; day $14=1.67$; day $21=2.26 \mathrm{ng} / \mathrm{mL}$ ) compared with those in cultures without AZT (means of HIV-1 p24: day $10=3.70$; day $14=12.23$; day $21=29.30 \mathrm{ng} / \mathrm{mL}$ ). Moreover, in $\mathrm{P}_{4}$-treated cells, AZT efficacy was lower (means of HIV-1 p24: day 14=1.67; day $21=2.26 \mathrm{ng} / \mathrm{mL})$ than in cultures without $\mathrm{P}_{4}(P<0.001)$ (means of HIV-1 p24: day $14=0.29$; day $21=0.48 \mathrm{ng} / \mathrm{mL}$ ).

Similarly, in co-infections, the HIV-1 p24 levels for AZT/valacyclovir-treated cultures were significantly lower (means of HIV-1 p24: day $10=0.22$; day $14=0.38$; day $21=0.65 \mathrm{ng} / \mathrm{mL}$ ) than those for cultures without AZT/valacyclovir (means of HIV-1 p24: day $10=0.55 \mathrm{ng} / \mathrm{mL}$; day $14=0.57 ;$ day $21=13.1 \mathrm{ng} / \mathrm{mL}$ ) (Fig. 5B). When similar experiments were repeated for $\mathrm{P}_{4}$-treated cells (Fig. 5B), HIV-1 viral load was 9-fold higher $(P<0.001)$ at day $21(137.1 \mathrm{ng} / \mathrm{mL}$ of $\mathrm{p} 24)$ compared with that in cultures without $\mathrm{P}_{4}(15.11 \mathrm{ng} / \mathrm{mL}$ of $\mathrm{p} 24)$. In addition, HIV-1 p24 levels did not decrease completely with $\mathrm{AZT} /$ valacyclovir treatment (day $10=0.55$; day $14=0.57$; day $21=13.12 \mathrm{ng} / \mathrm{mL}$ ) compared with cultures without AZT/valacyclovir (means of HIV-1 p24: day 10=3.60; day $14=12.48$; day $21=137.12 \mathrm{ng} / \mathrm{mL}$ ). Moreover, in $\mathrm{P}_{4^{-}}$ treated cells, AZT/valacyclovir efficacy was lower (means of HIV-1 p24: day $14=0.57$; day $21=13.12 \mathrm{ng} / \mathrm{mL}$ ) than that in cultures without $\mathrm{P}_{4}(P<0.001)$ (means of HIV-1 p24: day $14=0.38$; day $21=0.65 \mathrm{ng} / \mathrm{mL})$.

\section{$P_{4}$ supports HIV-1 replication and cell death}

Next, we wanted to study the effects of $\mathrm{P}_{4}$ treatment on primary cells and determine whether $\mathrm{P}_{4}$ treatment or HSV-2 co-infection increased HIV-1 replication and augmented cell death. We cultured PBMC cells collected from three different donors and treated them with $\mathrm{P}_{4}$ at similar concentrations of hormones used in the experiments with cell lines. The PBMC cells not treated with hormones served as a control. At 14d.p.i $\mathrm{P}_{4}$-treated mean of HIV-1 p24 levels of donor $2(81.6 \mathrm{ng} / \mathrm{mL})$ and donor $3 \quad(126.9 \mathrm{ng} / \mathrm{mL})$ was significantly $(P<0.05)$ higher than with $\mathrm{NH}$ donor $2(62 \mathrm{ng} / \mathrm{mL})$ and donor 3 $(61.5 \mathrm{ng} / \mathrm{mL})$. However, no significant differences were observed between $\mathrm{P}_{4}$-treated donor 1 (90 ng/mL) and $\mathrm{NH}$ donor $1(80.6 \mathrm{ng} / \mathrm{mL})$ (Fig. 6A), suggesting donor-to-donor variations in infectivity. When similar experiments were repeated for HSV-2 co-infection, at 14d.p.i. significant $(P<0.05)$ cell death and low HIV-1 p24 levels were noted for $\mathrm{P}_{4}$-treated donor $1(990 \mathrm{pg} / \mathrm{mL})$, donor $2(1160 \mathrm{pg} / \mathrm{mL})$ and donor $3(1880 \mathrm{pg} / \mathrm{mL})$ compared with $\mathrm{NH}$ donor $1(5000 \mathrm{pg} / \mathrm{mL})$, donor $2(6500 \mathrm{pg} / \mathrm{mL})$ and donor 3 (7240 pg/mL) (Fig. 6B). These results suggest that $\mathrm{P}_{4}$ enhances HIV-1/HSV-2 replication and leads to cell death in primary cells.

\section{Host gene expression profiling}

To further elucidate the cellular mechanisms in relation to $\mathrm{P}_{4}$-treated cells infected with HIV-1 or co-infected with HSV-2, mRNA gene expression profiling of major chemokines, cytokines and apoptosis-specific biological markers were analyzed.

Published by Bioscientifica Ltd. 


\section{a Donor 1 Donor 2 a Donor 3}

A
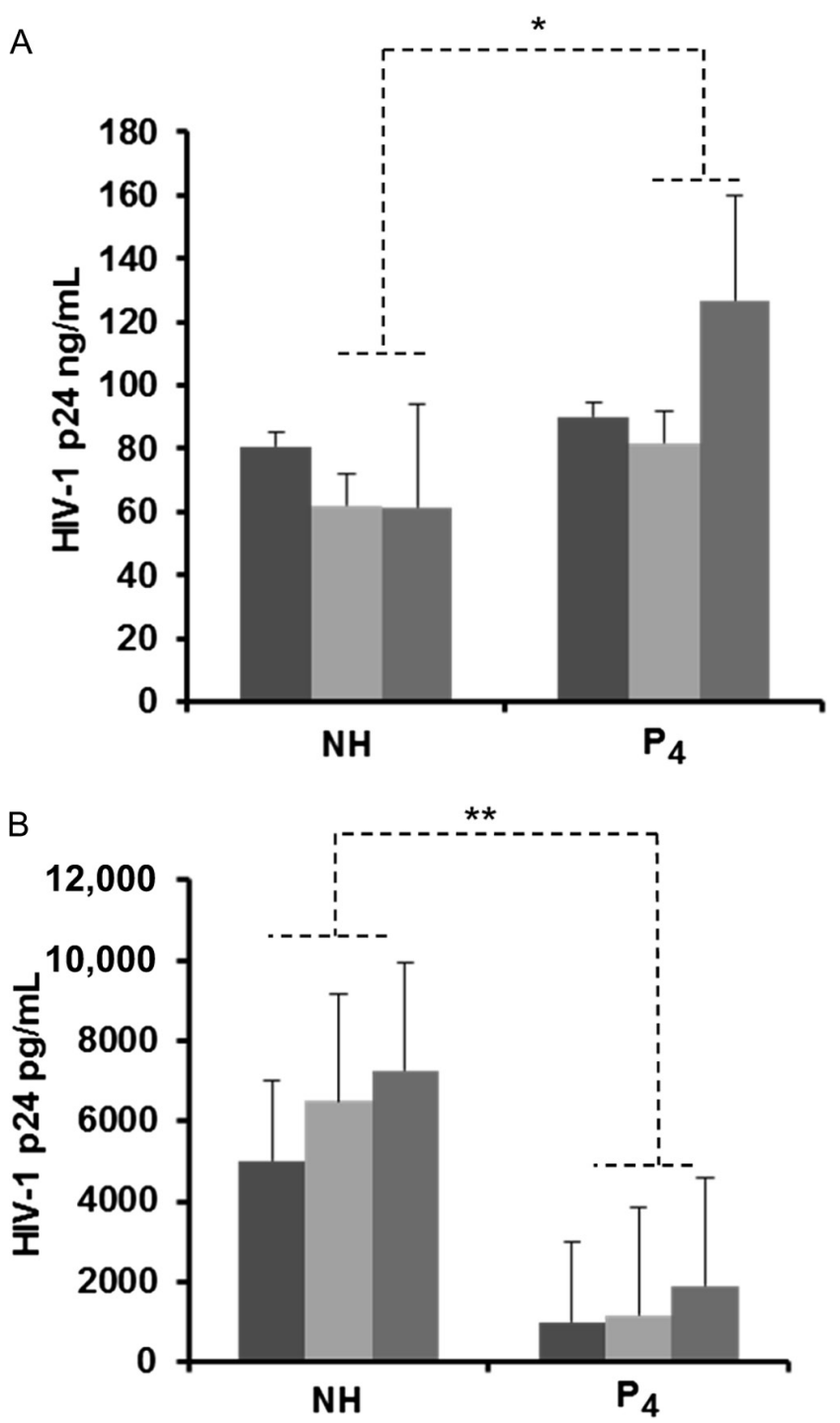

Figure 6

HIV-1 replication kinetics in primary PBMC cells either untreated $(\mathrm{NH})$ or treated with progesterone $\left(\mathrm{P}_{4}\right)$. (A) HIV-1 p24 levels are significantly higher $(P<0.05)$ for $\mathrm{P}_{4}$-treated donors $(2,3)$ compared with $\mathrm{NH}$. For donor 1, there was no significant differences in HIV-1 p24 levels between $\mathrm{NH}$ and $\mathrm{P}_{4}$ treatment. (B) Measure of HIV-1 p24 levels in HSV-2/HIV-1 co-infected donors had significantly low $(P<0.01)$ p24 levels in $\mathrm{P}_{4}$-treated cells compared with $\mathrm{NH}$. Error bars represent the standard errors of the means, and samples that are significant (*) and very significant $(* *)$ as determined by unpaired $t$-test.

A total of 84 genes encoding inflammatory cytokines/receptors, chemokines/receptors and others involved in inflammation were analyzed using the Human Inflammatory Cytokines and Receptors PCR Array. Cells were either $\mathrm{P}_{4}$ treated or untreated and infected with HIV-1 or HSV-2/HIV-1 for 7 days. The total nucleic acid was extracted, normalized and analyzed. Data were pooled from each experimental group (uninfected, NH-HIV-1, $\mathrm{P}_{4}$-HIV-1, NH-HIV-1/HSV-2 and $\mathrm{P}_{4}$-HIV-1/HSV-2) and analyzed with Web-based $\mathrm{RT}^{2}$ profiler PCR array data, version 3.5. Gene expression was evaluated on the basis of 2-fold upregulation or downregulation compared with uninfected controls. Based on earlier observations, $\mathrm{P}_{4}$-treated cells infected with HIV-1 and HSV-2 could modulate certain genes in support of pathogenesis. Hence, our analysis was focused on host gene expression profile for $\mathrm{P}_{4}$-treated cells with HIV-1 or HSV-2 co-infections. Our results indicate that relatively few genes (CCL15, CCL19, CCR6, IL36A and IFNA2) were differentially expressed with HIV infection (NH-HIV or without $\mathrm{P}_{4}$ treatment). Interestingly, when the expression profile was compared with $\mathrm{P}_{4}$-treated HIV-1-infected cells, several inflammatory genes were 2- to 15 -fold upregulated $(P<0.05)$ (Fig. 7A). Notably, chemokines CCL11, CCL13 and CCL23 and the receptors CCL13, CCR3, CCR6, CX3CR1 and XCR1 were 2- to 6-fold upregulated $(P<0.05)$ compared with HIV1-infected cells without $\mathrm{P}_{4}$ treatment or uninfected $\mathrm{P}_{4}$ treated controls. The cytokines IL36B and receptor IFNA2 were also 6- to 12-fold upregulated for HIV-1-infected $\mathrm{P}_{4}$-treated cells. In co-infection studies, chemokine and cytokine levels in HIV-1-infected and $\mathrm{P}_{4}$-treated cells were upregulated 2-410 higher than only HIV-1 infection (Fig. 7B). Notably, several-fold increase of CCL4, CXCL9, CCR5 and CXCR1 expression was observed. The cytokines IL22, IL10RA, IL13, IL13RA1, IL5RA and IL9 were 15- to 166-fold upregulated.

To identify host factors specifically involved in cell death due to infection, similar to the inflammatory response PCR array, an apoptosis PCR array of 84 genes was analyzed. For analysis, data were pooled from each experimental group (uninfected, NH-HIV-1, NH-HSV, NH-HIV-1/HSV-2， $\mathrm{P}_{4}$-control, $\mathrm{P}_{4}$-HIV-1 and $\mathrm{P}_{4}$-HIV-1/HSV-2). To elucidate the expression of apoptotic genes in cells co-infected with HSV-2/HIV-1, differential gene expression was analyzed and compared with the expression profile of $\mathrm{P}_{4}$-treated cells. Although most of the genes were not differentially expressed in cells infected with HIV-1 or HSV-2 alone, downregulation of anti-apoptotic factor BCL2L10 was consistently observed ( $>2$ fold) with $\mathrm{P}_{4}$-treated cells for both viruses (Fig. 8). In addition, TNFRSB10B was downregulated ( $>2$ fold) for HSV-2-infected cells with $\mathrm{P}_{4}$ treatment. In cells co-infected with HIV-1 and HSV-2, few other genes were upregulated, and genes BCL2L10 and TNFRSB10B were downregulated (>2 fold) for HSV-2/HIV-1-infected cells with $\mathrm{P}_{4}$. The downregulation of Bcl-2 was further

Published by Bioscientifica Ltd 
A

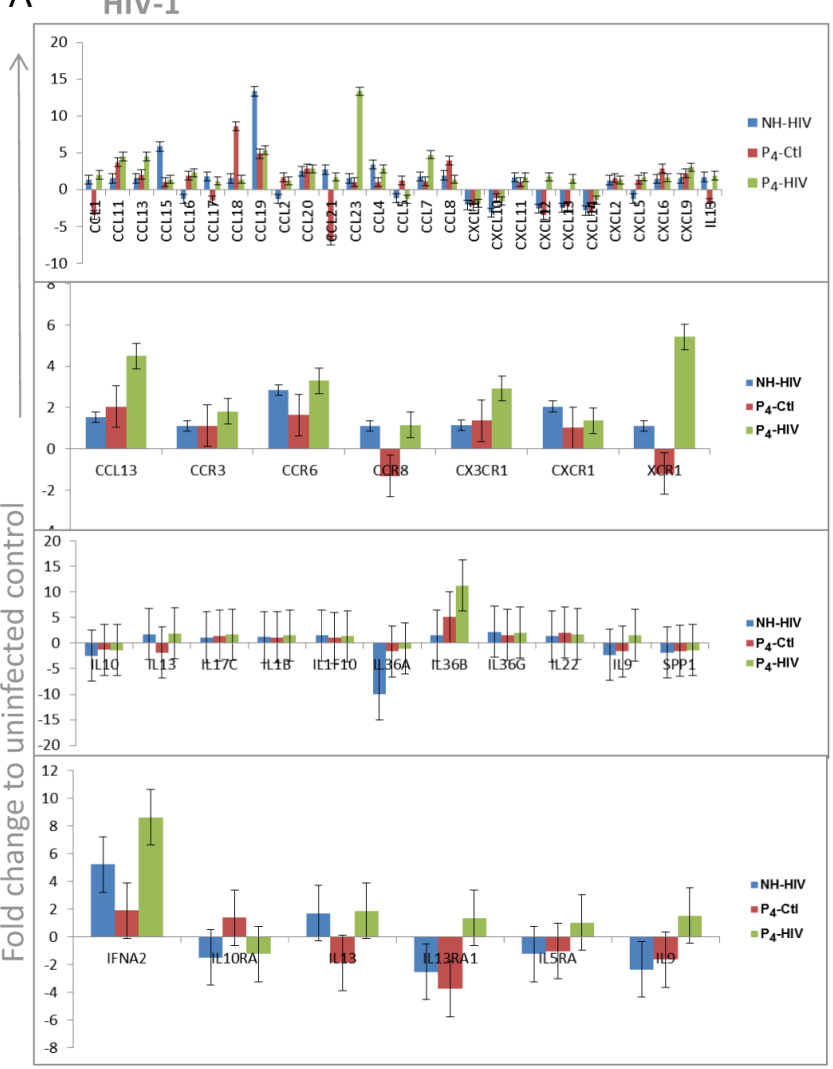

B HSV-2/HIV-1

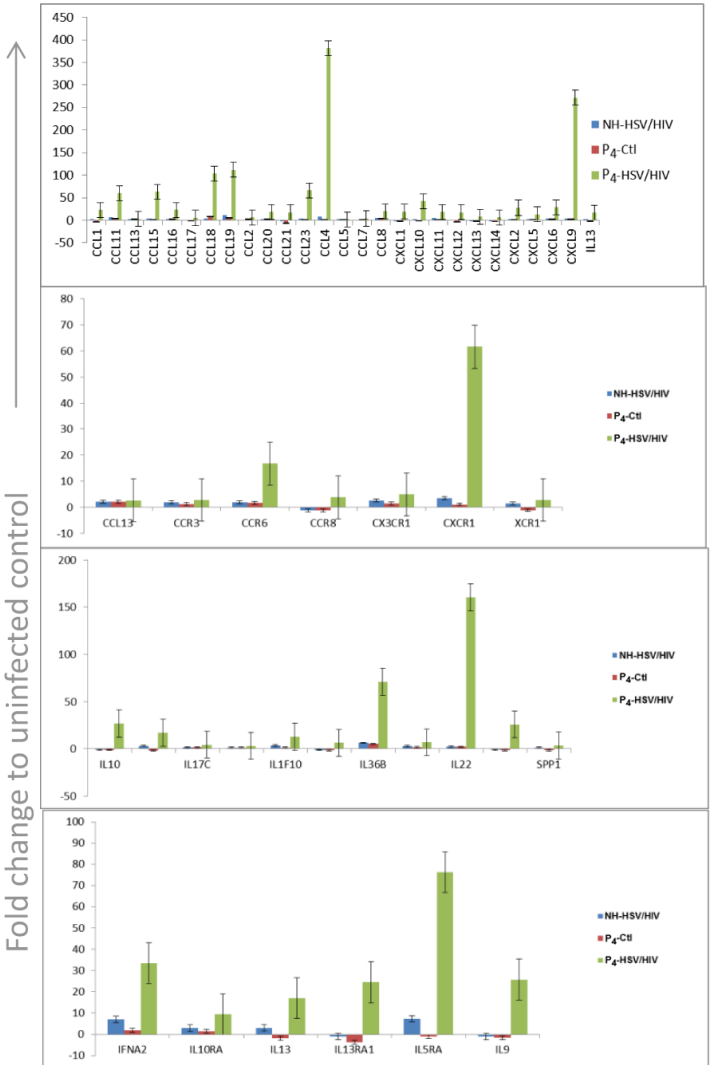

\section{Figure 7}

Cytokine and chemokine mRNA expression of HIV-1- and HSV-2-infected cells. The figure represents genes that are differentially expressed by progesterone treatment and HIV-1 or HSV-2/HIV-1 infections of 7 d.p.i. (A) and (B) Genes were evaluated on the basis of the criteria of at least 2-fold upregulation or downregulation compared with uninfected control. Error bars represent the standard errors of the means, and statistical significance of $P<0.05$ was determined by ANOVA.

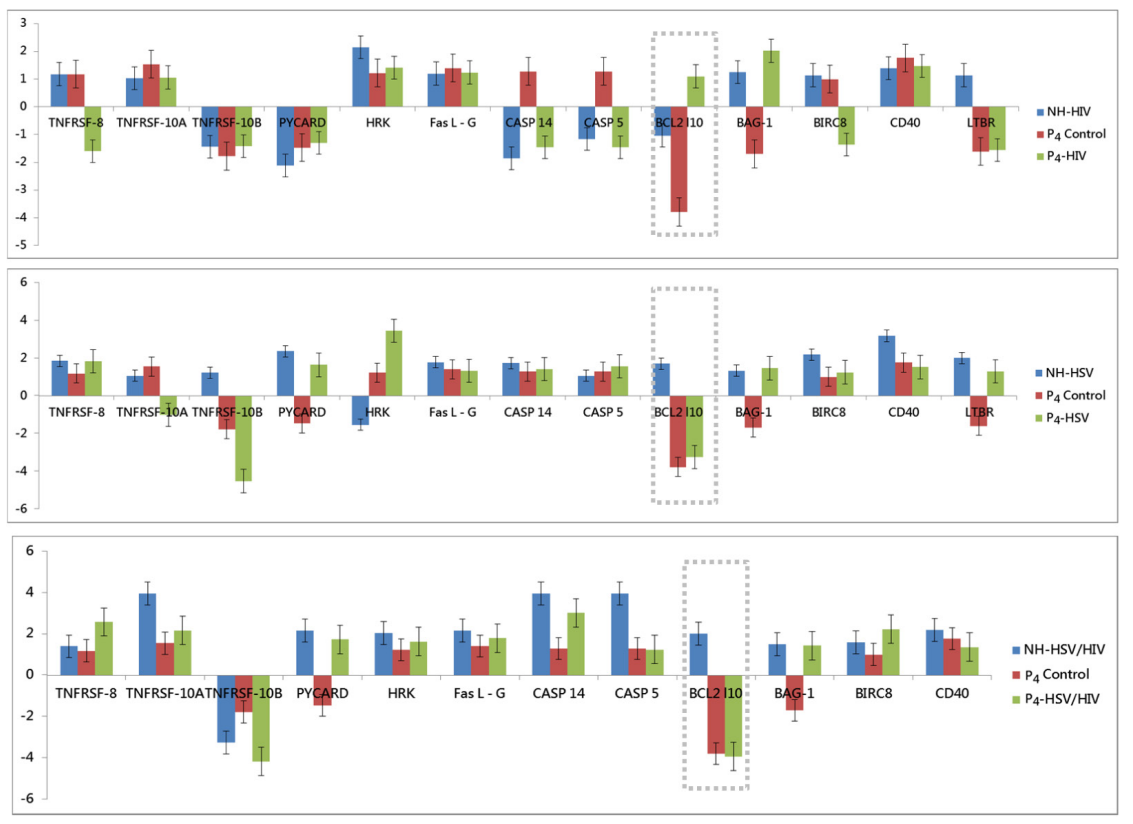

Figure 8

mRNA expression of apoptosis-related genes in HIV-1 and HSV-2 or co-infected cells. The figure represents genes that are differentially expressed by progesterone treatment and HIV-1 or HSV-2/HIV-1 infections of 7 d.p.i. (A), (B) and (C). Genes were evaluated on the basis of the criteria of at least a 2 -fold upregulation or downregulation compared with uninfected control. Error bars represent the standard errors of the means, and statistical significance of $P<0.05$ was determined by ANOVA. http://jme.endocrinology-journals.org DOI: 10.1530/JME-16-0138
C 2016 Society for Endocrinology Printed in Great Britain
Published by Bioscientifica Ltd. 
A

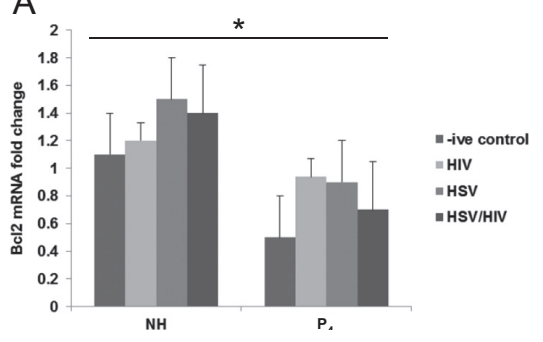

B

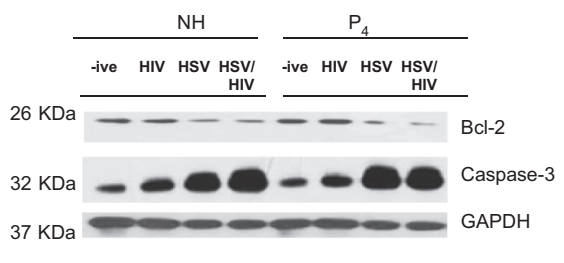

C

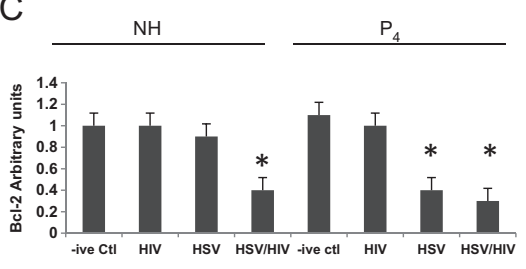

Figure 9

$\mathrm{Bcl} 2$ downregulation in response to progesterone $\left(\mathrm{P}_{4}\right)$-treated cells with HSV or HSV/HIV co-infections. (A) Bcl-2 expression was measured in duplicate from duplicate cultures by qRT-PCR at 7 d.p.i. Mean values are shown+s.E.M. The expression was calculated relative to GAPDH mRNA levels (bcl-2/GAPDH). ${ }^{*} P \leq 0.05$ when comparing NH and $\mathrm{P}_{4}$ from the same time point. Bars represent $\mathrm{Bcl} 2$ expression from uninfected negative control (-ive control), HIV or HSV or HSV/HIV co-infection. (B) Proteins were detected by Western blot analysis using antibodies to Bcl-2, Caspase 3 and GAPDH. (C) Densitometry for Bcl2 blot was performed using ImageJ software. Arbitrary units represent protein-level analysis with respect to without or with $\mathrm{P}_{4}$ treatment. Significant reduction in Bcl-2 expression was noted as $\left.{ }^{*}\right)$ compared to uninfected cells without $\mathrm{P}_{4}$ treatment.

confirmed with qPCR and at the protein level by Western blot analysis.

\section{$\mathrm{P}_{4}$ regulation of $\mathrm{Bcl}-2 \mathrm{mRNA}$ and protein levels}

To confirm the PCR array data of Bcl-2 down-regulation by $\mathrm{P}_{4}$, we performed qPCR for Bcl-2 mRNA expression in $\mathrm{P}_{4}$-treated cells infected with HIV-1 or co-infected with HSV-2. At 7 d.p.i, RNA was extracted and quantified by GAPDH normalization. Different patterns of host gene expression were observed (Fig. 9A). In cells not treated with $\mathrm{P}_{4}$, consistent increase of Bcl-2 was observed for HIV-1- or HSV-2-infected cells. Cells treated with $\mathrm{P}_{4}$ had significant $(P<0.05)$ down-regulation of Bcl-2 $\left(\mathrm{P}_{4}\right.$ uninfected, infected with HIV or HSV-2 and HSV-2/HIV-1). These observations were further confirmed at the protein level using immunoblotting, which showed that $\mathrm{P}_{4}$-treated uninfected cells and infected with HSV-2/HIV-1 had lower expression of Bcl-2 than $\mathrm{P}_{4}$-untreated cells (Fig. 9B), and densitometry was performed on bands using ImageJ software (Fig. 9C). Cells treated with $\mathrm{P}_{4}$ and infected with HIV-1 or HSV-2 show Bcl-2 expression due to the fact virus-host interaction this phenomenon diminishes at later infection time point. In addition, caspase 3 protein expression was evaluated to confirm extensive cell death of co-infected cells. As expected, increased caspase-3 protein expression (Fig. 9B) was noted with co-infected cells treated with $\mathrm{P}_{4}$ or untreated.

\section{Increased association of $\mathbf{P}_{4}$ with PRE region of Bcl-2 promoter}

This is the first study to show that $\mathrm{P}_{4}$ treatment augments HIV-1 replication, which increases several folds in the presence of HSV-2 co-infection by the downregulation of
A

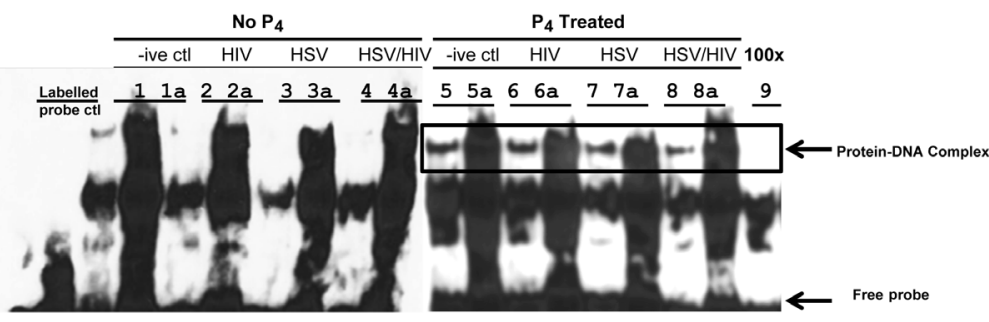

Nuclear extract

Mutant probe

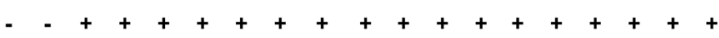

Wild labelled probe

Excess cold un
labelled probe

B
Wild 5'biotin-GACA GAGGATC ${ }^{*}$ AT ${ }^{*}$ CTGTACTTAAA 3'

$\longleftrightarrow$ PRE $\longrightarrow$
Figure 10

Electrophoretic mobility shift assay (EMSA) analysis of $\mathrm{P}_{4}$-binding region of $\mathrm{BCl}-2$ promoter. (A) EMSA was performed using samples of nuclear extracts $(3 \mu \mathrm{g})$ from CEMss cells either untreated (1-4) or treated with progesterone for $2 \mathrm{~h}(5-8)$ and infected with HIV or HSV as indicated for $2 \mathrm{~h}$. Each lane in no $\mathrm{P}_{4}$ or $\mathrm{P}_{4}$-treated cells represents wild-type or mutant probe incubation with nuclear factor. The arrow indicate DNA-protein complex and free DNA. The intensity of DNA-protein complex partially decreased in lane 9 for competition studies with 100 -fold excess of cold unlabeled and labeled probe. The figure represents one of the three independently performed experiments. (B) Biotin-labeled oligonucleotide probes containing putative PRE-binding sites in box and its flanking sequence. In mutant probe, bases with $\left(^{*}\right)$ were replaced as A's. 
the Bcl-2 molecule. We wanted to explore the mechanism of Bcl-2 down-regulation by $\mathrm{P}_{4}$ treatment. Previously, it was reported that PRE is present in the Bcl-2 promoter thereby modulating Bcl-2 gene expression in $\mathrm{P}_{4}$-treated cells. To test whether co-infection in the presence of $\mathrm{P}_{4}$ increases the association of transcription factors with PRE, nuclear proteins were extracted from cells cultured with or without $\mathrm{P}_{4}$ and infected with HIV-1, HSV-2 or co-infected for $4 \mathrm{~h}$ and analyzed.

The Bcl-2 promoter region of $\mathrm{P}_{4}$ response element (PRE) was identified through the Web portal Transcription Element Search Site (TESS, 2011). PCR was performed to amplify the $242 \mathrm{bp}$ fragment of the Bcl-2 promoter containing the PRE and confirming the presence of the sequence within the amplified product. The biotinylated PRE probes were designed for binding in electrophoretic mobility shift assay (EMSA). Extracted nuclear proteins from $\mathrm{P}_{4}$-untreated (uninfected and infected with HIV1, HSV-2 or co-infected) or $\mathrm{P}_{4}$-treated $\left(\mathrm{P}_{4}\right.$ uninfected and infected with $\mathrm{P}_{4}$-HIV-1, $\mathrm{P}_{4}$-HSV-2 or $\mathrm{P}_{4}$-co-infected) cells of different experimental conditions (lanes 1-8) were incubated with biotinylated PRE probe or mutant probe (1a-8a) of transcription factor-binding region for determining PRE association. The PRE probe and mutant probe were loaded as pairs for each experimental condition, in which lanes 1-4 represent no $\mathrm{P}_{4}$ treatment and lanes 5-8 indicate treatment with $\mathrm{P}_{4}$. It was inferred from Fig. 10 that DNA-protein complex was formed when the biotin labeled probe was incubated with nuclear extract (4-8). In lane 9, incubation with excess of cold unlabeled probe (100-fold) decreased labeled probe binding, demonstrating specificity. In addition, mutant labeled probe (lanes 1a-8a) increased binding of other nuclear proteins. These data indicate that nuclear factors induced by $\mathrm{P}_{4}$ bind to $\mathrm{Bcl}-2$ promoter specifically.

\section{Discussion}

The use of progestin $\left(\mathrm{P}_{4}\right.$ analog) as contraceptive pills for HIV-1-positive women has been extensively debated recently with regard to its ability to increase HIV-1 risk or not (Colvin \& Harrison 2015, Morrison et al. 2015, Ralph et al. 2015). Some studies indicate no link between contraceptive use and risk of HIV-1 (Heffron et al. 2013, Polis et al. 2014), whereas others reported significant risk with contraceptive use (Heffron et al. 2012, Haddad et al. 2014). Recently, by examining individual participant data instead of an aggregate of different studies, an increase in risk was found to be associated with the use of $\mathrm{P}_{4}$-containing contraceptives (Morrison et al. 2015). Considering the immediate need in the prevention of HIV-1 in women, we investigated the basic mechanism of $\mathrm{P}_{4}$ effects on HIV-1 pathogenesis and with co-infection of HSV-2. First, we investigated the cell type that could infect HIV-1 and HSV-2. Previously, it was shown that CEMss cell line is capable of infection by these two viruses (Legoff et al. 2007). We tested the infectivity of these two viruses at the indicated $(5 \mathrm{ng} / \mathrm{mL}$ of HIV-1 p24 or 1 p.f.u. HSV2) concentrations, which were normalized for optimal infectivity after multiple experiments. Infectivity was determined by rise in titer from time zero. To evaluate the effects of steroid hormones on replication of HIV-1 and HSV-2, we tested testosterone and estradiol along with $\mathrm{P}_{4}$. The measurable HIV-1 p24 levels at 7 d.p.i in both untreated and hormone-treated cultures indicate no inhibition of hormones for HIV-1 replication. In co-infected cultures, we quantified both viruses simultaneously using an in-house multiplex quantitative TaqMan assay. An increase in virus titer was observed for both viruses from time zero and could be quantitated. In addition, HIV-1 viral load levels for cultures with and without hormone treatment showed a similar trend compared with p24 quantification (Fig. 1A and B). Although our present work focuses on $\mathrm{P}_{4}, \mathrm{E}_{2}$ and testosterone hormones significantly increase HIV-1 viral load. Interestingly, $\mathrm{E}_{2}$ or $\mathrm{E}_{2} / \mathrm{P}_{4}$ mix increase $\mathrm{HSV}$-2 viral load but not $\mathrm{P}_{4}$ or testosterone, which may require further functional studies to validate HSV-2 replication kinetics in the presence of hormones.

Previously, several studies had indicated that $\mathrm{P}_{4}$ or its synthetic form increased HIV-1 susceptibility or risk of infection (Asin et al. 2008, Ramjee \& Wand 2012, Ferreira et al. 2014) in a macaque model using subcutaneous implants of $\mathrm{P}_{4}$ which increased vaginal SIV transmission several fold (Marx et al. 1996). Similar to these earlier studies, we also observed that treatment with steroid hormones increased HIV-1 viral load levels in culture supernatants. Several studies have shown that HSV-2 infection increases HIV-1 acquisition (Schacker et al. 1998, Freeman et al. 2006) and pathogenesis (Sartori et al. 2011, Rollenhagen et al. 2014). Hence, HSV-2-infected individuals are at high risk for HIV-1 co-infection and that HSV-2 incidence among HIV-1 sero-discordant couples increases the risk of HIV-1 transmission (Muiru et al. 2013). To verify this observation made at the population level, using an in vitro cell culture system, we tested several combinations of hormone and virus treatment to determine their effect on HIV-1 viral load. In cells co-infected with HSV-2 and or vice versa, we observed significant differences in viral load between the different combinations of hormone treatment (Fig. 2A,

Published by Bioscientifica Ltd. 
B, C and D) except cells treated with $\mathrm{E}_{2}$ (Fig. 2C), $\mathrm{P}_{4}$ and testosterone (Fig. 2B). It is interesting to note that $\mathrm{P}_{4}$ supports HIV-1 replication in cells treated with $\mathrm{P}_{4}$ only (Fig. $2 \mathrm{~A}$ ) or mixed with $\mathrm{E}_{2} / \mathrm{P}_{4}$ (Fig. $2 \mathrm{~A}, \mathrm{C}$ and $\mathrm{D}$ ). Conversely, $\mathrm{E}_{2}$ supports HSV-2 replication in cells treated with $\mathrm{E}_{2}$ only or mixed with $\mathrm{E}_{2} / \mathrm{P}_{4}$ (Fig. 2B). Although sex hormones support HIV-1 or HSV-2 replication, significant cell death was noted in co-infected cultures at 14 d.p.i of $\mathrm{P}_{4}$-treated cells. We ruled out hormone toxicity by cell viability analysis from multiple experiments with and without $\mathrm{P}_{4}$ treatment and co-infection with HIV-1 or HSV-2. Up to day 9, >85\% cells were viable (Figs 3 and 4). Thus, in early part of HIV-1 infection (up to day 9), $P_{4}$ did not decrease the cell viability but augments HIV-1 replication. However, significant loss of cells was noted with co-infected cultures treated with $\mathrm{P}_{4}$. When we compared cell viability with p24 levels of co-infected cells, lower p24 levels were noted with $\mathrm{P}_{4}$ and $\mathrm{E}_{2} / \mathrm{P}_{4}$ treatment at 14 d.p.i. (Fig. 3), which may be due to the decrease in cell numbers as the infection progresses.

Previous studies had reported that the use of $\mathrm{P}_{4}$-onlybased contraception may be associated with a small risk of HIV-1 infection for patients on antiviral therapy. Even though recent reports indicate that the contraceptive DMPA increases risk of HIV-1, there is no link between HSV-2 shedding, antiviral therapy and contraceptive use (McClelland et al. 2002, Morrison et al. 2007). In this study, we investigated the effect of $\mathrm{ARVs}$ in $\mathrm{P}_{4}$-treated cells. In cell cultures, it was observed that p24 levels decreased with AZT (inhibitor of HIV-1) or valacyclovir (inhibitor of $\mathrm{HSV}$-2) treatment. However, in $\mathrm{P}_{4}$-treated cells, a significant increase in HIV-1 p24 levels were noted (Fig. 5) for HIV-1 or HIV-1/HSV-2 co-infections, which is in agreement with earlier observations that hormonal contraceptive users had lower viral load reduction than non-contraceptive users (Johnson et al. 2011).

To further confirm the effects of $\mathrm{P}_{4}$ on HIV-1, we obtained PBMCs from three blood donors, treated them with $\mathrm{P}_{4}$ and infected them with HIV-1 alone or co-infected with HSV-2. We found that there were significantly higher p24 levels when the cells were exposed to $\mathrm{P}_{4}$ (Fig. 6A). Similarly, when PBMCs are co-infected with HSV-2 and exposed to $\mathrm{P}_{4}$, significant cell death and lower p24 levels were observed (Fig. 6B). This observation with primary cells confirms our earlier finding with CEMss cell line (Fig. 3). It should also be noted that these findings are not consistent for all donors suggesting that there may be donor-to-donor variations.

The $\mathrm{P}_{4}$-exposed cells infected with HIV-1 or co-infected with HSV-2 upregulate certain inflammatory cytokines and chemokines. Notably, upregulation of CCL23 was observed with HIV-1/P $\mathrm{P}_{4}$-treated cells, which have not been shown previously in the context of HIV-1 infection. Upregulation of other pro-inflammatory cytokines, such as XCR1 supports HIV-1 replication (Vasilescu et al. 2007), and IL-36 $\beta$ is indicative of the activation of the MAPK and NF-кB pathway (Tripodi et al. 2012). These results suggest that $\mathrm{P}_{4}$ induces pro-inflammatory responses for HIV-1 infection (Fig. 7A). When cells are co-infected with HSV-2, specific chemokines such as CCL4 and CXCL9 were upregulated (Fig. 7B). Our observations support the previous studies in that CXCL9 upregulation was observed in HSV-2 infection (Huang et al. 2012, Rollenhagen et al. 2014) and activation of HIV-1 in target cells. In addition, elevation of IL22 and IL5 are indicative of active replication of HIV-1 or HSV-2, which was reported previously. These results suggest that $\mathrm{P}_{4}$ plays an important role in cellular immunity to infection.

We focused our attention on the extensive cell death in $\mathrm{P}_{4}$-treated and co-infected cultures. We used the apoptosis array to identify biomolecules involved in cell death. We observed Bcl-2 down-regulation by $\mathrm{P}_{4}$, which may lead to active replication of HIV-1 or HSV-2 in co-infected cells with subsequent cell death (Fig. 8). Several other studies have reported that Bcl-2 down-regulation by HIV-1 leads to oxidative stressmediated apoptosis and subsequent depletion of CD4T cells (Strack et al. 1996, Cummins \& Badley 2010). In addition, previously it was reported that downregulation of Bcl-2 by HSV-2 leads to low productive infection and apoptosis (Sciortino et al. 2006). In this study, we also observed similar effects of lower viral loads and extensive cell death with co-infections. The down-regulation of $\mathrm{Bcl}-2$ by $\mathrm{P}_{4}$ and co-infection was subsequently confirmed by qPCR and Western blot (Fig. 9A and B). To further support our observation that $\mathrm{P}_{4}$ treatment leads to cell death, we noted increased caspase-3 expression in co-infected cells, which was reported previously for both HIV-1 and HSV-2 (Cicala et al. 1999, Jones et al. 2003).

The data presented here clearly show that $\mathrm{P}_{4}$ supports the replication of two synergistic viruses. Previously, it was shown that Bcl-2 may have a PRE in its promoter sequence (Viegas et al. 2004, Yin et al. 2007). We show PRE-like sequence in Bcl-2 promoter region of $\mathrm{P}_{4}$-treated cells (Fig. 10). This observation supports the notion that $P_{4}$ has a role in transcriptional regulation of Bcl-2. In HIV-1/ HSV-2 co-infected cells, the combined effects of viral and $\mathrm{P}_{4}$ may be one of the mechanisms that may augment viral

Published by Bioscientifica Ltd 
replication. In conclusion, our results provide insights into molecular and cellular mechanisms by which $\mathrm{P}_{4}$ may enhance the susceptibility to infection of two viruses presented here.

\section{Declaration of interest}

The authors declare that there is no conflict of interest that could be perceived as prejudicing the impartiality of the research reported.

\section{Funding}

This work was funded by an intramural grant from the FDA's Office of Women's Health.

\section{Author contribution statement}

$\mathrm{V} R$ drafted the manuscript and made substantial contributions to conception, design, analysis and interpretation of data; $\mathrm{W} X$ and $J \mathrm{~T}$ performed Western blot; Y G provided technical assistance; K D provided suggestions for the work and reviewed the manuscript; and I $\mathrm{H}$ was involved in concept, design, data interpretation and supervision of the project and provided input in revising the manuscript critically for publication.

\section{Disclaimer}

The findings and conclusions in this article have not been formally disseminated by the FDA and should not be construed to represent any Agency determination or policy.

\section{Acknowledgements}

The authors wish to acknowledge Drs Mohan Kumar and Subhash Dhawan for critical review of this manuscript.

\section{References}

Asin SN, Heimberg AM, Eszterhas SK, Rollenhagen C \& Howell AL 2008 Estradiol and progesterone regulate HIV type 1 replication in peripheral blood cells. AIDS Research and Human Retroviruses 24 701-716. (doi:10.1089/aid.2007.0108)

Baeten JM, Benki S, Chohan V, Lavreys L, McClelland RS, Mandaliya K, Ndinya-Achola JO, Jaoko W \& Overbaugh J 2007 Hormonal contraceptive use, herpes simplex virus infection, and risk of HIV-1 acquisition among Kenyan women. AIDS 21 1771-1777. (doi:10.1097/QAD.0b013e328270388a)

Benjamin RJ, Busch MP, Fang CT, Notari EP, Puren A, Schoub BD, Tobler LH, Hogrefe W, du PHA, Stramer SL, et al. 2008 Human immunodeficiency virus-1 infection correlates strongly with herpes simplex virus-2 (genital herpes) seropositivity in South African and United States blood donations. Transfusion 48 295-303. (doi:10.1111/j.1537-2995.2007.01523.x)

Cabrera-Munoz E, Fuentes-Romero LL, Zamora-Chavez J, CamachoArroyo I \& Soto-Ramirez LE 2012 Effects of progesterone on the content of CCR5 and CXCR4 coreceptors in PBMCs of seropositive and exposed but uninfected Mexican women to HIV-1. Journal of Steroid Biochemistry and Molecular Biology 132 66-72. (doi:10.1016/j. jsbmb.2012.02.001)

Cicala C, Arthos J, Ruiz M, Vaccarezza M, Rubbert A, Riva A, Wildt K, Cohen O \& Fauci AS 1999 Induction of phosphorylation and intracellular association of CC chemokine receptor 5 and focal adhesion kinase in primary human $\mathrm{CD} 4+\mathrm{T}$ cells by macrophagetropic HIV envelope. Journal of Immunology 163 420-426.

Colvin CJ \& Harrison A 2015 Broadening the debate over HIV and hormonal contraception. Lancet Infectious Diseases 15 135-136. (doi:10.1016/S1473-3099(14)71076-X)

Cummins NW \& Badley AD 2010 Mechanisms of HIV-associated lymphocyte apoptosis: 2010. Cell Death and Disease 1 e99. (doi:10.1038/cddis.2010.77)

Czabotar PE, Westphal D, Dewson G, Ma S, Hockings C, Fairlie WD, Lee EF, Yao S, Robin AY, Smith BJ, et al. 2013 Bax crystal structures reveal how BH3 domains activate Bax and nucleate its oligomerization to induce apoptosis. Cell 152 519-531. (doi:10.1016/j.cell.2012.12.031)

Ferreira VH, Dizzell S, Nazli A, Kafka JK, Mueller K, Nguyen PV, Tremblay MJ, Cochrane A \& Kaushic C 2014 Medroxyprogesterone acetate regulates HIV-1 uptake and transcytosis but not replication in primary genital epithelial cells, resulting in enhanced T-cell infection. Journal of Infectious Diseases 211 1745-1756. (doi:10.1093/ infdis/jiu832)

Foss AM, Vickerman PT, Mayaud P, Weiss HA, Ramesh BM, Reza-Paul S, Washington R, Blanchard J, Moses S, Lowndes CM, et al. 2011 Modelling the interactions between herpes simplex virus type 2 and HIV: implications for the HIV epidemic in southern India. Sexually Transmitted Infections 87 22-27. (doi:10.1136/sti.2009.041699)

Freeman EE, Weiss HA, Glynn JR, Cross PL, Whitworth JA \& Hayes RJ 2006 Herpes simplex virus 2 infection increases HIV acquisition in men and women: systematic review and meta-analysis of longitudinal studies. AIDS 20 73-83. (doi:10.1097/01. aids.0000198081.09337.a7)

Haddad LB, Polis CB, Sheth AN, Brown J, Kourtis AP, King C, Chakraborty R \& Ofotokun I 2014 Contraceptive methods and risk of HIV acquisition or female-to-male transmission. Current HIV/AIDS Reports 11 447-458. (doi:10.1007/s11904-014-0236-6)

Heffron R, Mugo N, Ngure K, Celum C, Donnell D, Were E, Rees H, Kiarie J \& Baeten JM 2012 Hormonal contraceptive use and risk of HIV-1 disease progression. AIDS 27 261-267. (doi:10.1097/ QAD.0b013e32835ad473)

Heffron R, Mugo N, Ngure K, Celum C, Donnell D, Were E, Rees H, Kiarie J, Baeten JM \& Partners in Prevention HSVHIV Transmission Study Team 2013 Hormonal contraceptive use and risk of HIV-1 disease progression. AIDS 27 261-267. (doi:10.1097/ QAD.0b013e32835ad473)

Huang W, Hu K, Luo S, Zhang M, Li C, Jin W, Liu Y, Griffin GE, Shattock RJ \& Hu Q 2012 Herpes simplex virus type 2 infection of human epithelial cells induces CXCL9 expression and CD4+ T cell migration via activation of $\mathrm{p} 38$-CCAAT/enhancer-binding proteinbeta pathway. Journal of Immunology 188 6247-6257. (doi:10.4049/ jimmunol.1103706)

Johnson D, Kempf M-C, Wilson CM \& Shrestha S 2011 Hormonal contraceptive use and response to antiretroviral therapy among adolescent females. HIV \& AIDS Review 10 65-69. (doi:10.1016/j. hivar.2011.05.002)

Joint United Nations Programme on HIV/AIDS 2013 UNAIDS Report on the Global AIDS Epidemic. Geneva, Switzerland: UNAIDS. (available at: http://www.unaids.org/sites/default/files/media_asset/UNAIDS_ Global_Report_2013_en_1.pdf)

Jones CA, Fernandez M, Herc K, Bosnjak L, Miranda-Saksena M, Boadle RA \& Cunningham A 2003 Herpes simplex virus type 2 induces rapid cell death and functional impairment of murine dendritic cells in vitro. Journal of Virology 77 11139-11149. (doi:10.1128/JVI.77.20.11139-11149.2003)

Kyurkchiev D, Bochev I, Ivanova-Todorova E, Mourdjeva M, Oreshkova T, Belemezova K \& Kyurkchiev S 2014 Secretion of immunoregulatory cytokines by mesenchymal stem cells. World Journal of Stem Cells 6 552-570. (doi:10.4252/wjsc.v6.i5.552) 
Legoff J, Bouhlal H, Lecerf M, Klein C, Hocini H, Si-Mohamed A, Muggeridge M \& Belec L 2007 HSV-2- and HIV-1- permissive cell lines co-infected by HSV-2 and HIV-1 co-replicate HSV-2 and HIV-1 without production of HSV-2/HIV-1 pseudotype particles. Virology Journal 4 2. (doi:10.1186/1743-422X-4-2)

Livak KJ \& Schmittgen TD 2001 Analysis of relative gene expression data using real-time quantitative PCR and the 2(-Delta Delta C(T)) method. Methods 25 402-408. (doi:10.1006/meth.2001.1262)

Marx PA, Spira AI, Gettie A, Dailey PJ, Veazey RS, Lackner AA, Mahoney CJ, Miller CJ, Claypool LE, Ho DD, et al. 1996 Progesterone implants enhance SIV vaginal transmission and early virus load. Nature Medicine 2 1084-1089. (doi:10.1038/nm1096-1084)

McClelland RS, Wang CC, Richardson BA, Corey L, Ashley RL, Mandaliya K, Ndinya-Achola J, Bwayo JJ \& Kreiss JK 2002 A prospective study of hormonal contraceptive use and cervical shedding of herpes simplex virus in human immunodeficiency virus type 1-seropositive women. Journal of Infectious Diseases $\mathbf{1 8 5}$ 1822-1825. (doi:10.1086/340639)

Morrison CS, Richardson BA, Mmiro F, Chipato T, Celentano DD, Luoto J, Mugerwa R, Padian N, Rugpao S, Brown JM, et al. 2007 Hormonal contraception and the risk of HIV acquisition. AIDS $\mathbf{2 1}$ 85-95. (doi:10.1097/QAD.0b013e3280117c8b)

Morrison CS, Skoler-Karpoff S, Kwok C, Chen PL, van de Wijgert J, Gehret-Plagianos M, Patel S, Ahmed K, Ramjee G, Friedland B, et al. 2012 Hormonal contraception and the risk of HIV acquisition among women in South Africa. AIDS 26 497-504. (doi:10.1097/ QAD.0b013e32834fa13d)

Morrison CS, Chen PL, Kwok C, Baeten JM, Brown J, Crook AM, Van Damme L, Delany-Moretlwe S, Francis SC, Friedland BA, et al. 2015 Hormonal contraception and the risk of HIV acquisition: an individual participant data meta-analysis. PLoS Medicine $\mathbf{1 2}$ e1001778. (doi:10.1371/journal.pmed.1001778)

Muiru AN, Guthrie BL, Bosire R, Merkel M, Liu AY, Choi RY, LohmanPayne B, Gatuguta A, Mackelprang RD, Kiarie JN, et al. 2013 Incident HSV-2 infections are common among HIV-1-discordant couples. Journal of Infectious Diseases 208 1093-1101. (doi:10.1093/infdis/jit303)

Perrot-Applanat M, Deng M, Fernandez H, Lelaidier C, Meduri G \& Bouchard P 1994 Immunohistochemical localization of estradiol and progesterone receptors in human uterus throughout pregnancy: expression in endometrial blood vessels. Journal of Clinical Endocrinology and Metabolism 78 216-224. (doi:0.1210/jcem.78.1.8288707)

Polis CB, Phillips SJ, Curtis KM, Westreich DJ, Steyn PS, Raymond E, Hannaford P \& Turner AN 2014 Hormonal contraceptive methods and risk of HIV acquisition in women: a systematic review of epidemiological evidence. Contraception 90 360-390. (doi:10.1016/j. contraception.2014.07.009)

Ragupathy V, Devadas K, Tang S, Wood O, Lee S, Dastyer A, Wang X, Dayton A \& Hewlett I 2013 Effect of sex steroid hormones on replication and transmission of major HIV subtypes. Journal of Steroid Biochemistry and Molecular Biology 138 63-71. (doi:10.1016/j. jsbmb.2013.03.002)

Ralph LJ, McCoy SI, Shiu K \& Padian NS 2015 Hormonal contraceptive use and women's risk of HIV acquisition: a meta-analysis of observational studies. Lancet Infectious Diseases 15 181-189. (doi:10.1016/S1473-3099(14)71052-7)

Ramjee G \& Wand H 2012 Population-level impact of hormonal contraception on incidence of HIV infection and pregnancy in women in Durban, South Africa. Bulletin of the World Health Organization 90 748-755. (doi:10.2471/BLT.12.105700)

Rollenhagen C, Lathrop MJ, Macura SL, Doncel GF \& Asin SN 2014 Herpes simplex virus type-2 stimulates HIV-1 replication in cervical tissues: implications for HIV-1 transmission and efficacy of anti-
HIV-1 microbicides. Mucosal Immunology 7 1165-1174. (doi:10.1038/ mi.2014.3)

Sartori E, Calistri A, Salata C, Del Vecchio C, Palu G \& Parolin C 2011 Herpes simplex virus type 2 infection increases human immunodeficiency virus type 1 entry into human primary macrophages. Virology Journal 8 166. (doi:10.1186/1743-422X-8-166)

Schacker T, Ryncarz AJ, Goddard J, Diem K, Shaughnessy M \& Corey L 1998 Frequent recovery of HIV-1 from genital herpes simplex virus lesions in HIV-1-infected men. JAMA 280 61-66. (doi:10.1001/jama.280.1.61)

Sciortino MT, Perri D, Medici MA, Grelli S, Serafino A, Borner C \& Mastino A 2006 Role of Bcl-2 expression for productive herpes simplex virus 2 replication. Virology 356 136-146. (doi:10.1016/j. virol.2006.08.001)

Strack PR, Frey MW, Rizzo CJ, Cordova B, George HJ, Meade R, Ho SP, Corman J, Tritch R \& Korant BD 1996 Apoptosis mediated by HIV protease is preceded by cleavage of Bcl-2. PNAS 93 9571-9576. (doi:10.1073/pnas.93.18.9571)

Thurman AR \& Doncel GF 2012 Herpes simplex virus and HIV: genital infection synergy and novel approaches to dual prevention. International Journal of STD \& AIDS 23 613-619. (doi:10.1258/ijsa.2012.011356)

Tripodi D, Conti F, Rosati M, Maccauro G, Saggini A, Cianchetti E, Angelucci D, Fulcheri M, Tete S, Salini V, et al. 2012 IL-36 a new member of the IL-1 family cytokines. Journal of Biological Regulators and Homeostatic Agents 26 7-14.

Tsujimoto Y 1998 Role of Bcl-2 family proteins in apoptosis: apoptosomes or mitochondria? Genes to Cells 3 697-707. (doi:10.1046/j.1365-2443.1998.00223.x)

Vasilescu A, Terashima Y, Enomoto M, Heath S, Poonpiriya V, Gatanaga H, Do H, Diop G, Hirtzig T, Auewarakul P, et al. 2007 A haplotype of the human CXCR1 gene protective against rapid disease progression in HIV-1+ patients. PNAS 104 3354-3359. (doi:10.1073/pnas.0611670104)

Viegas LR, Vicent GP, Baranao JL, Beato M \& Pecci A 2004 Steroid hormones induce bcl-X gene expression through direct activation of distal promoter P4. Journal of Biological Chemistry 279 9831-9839. (doi:10.1074/jbc.M312402200)

Vishwanathan SA, Guenthner PC, Lin CY, Dobard C, Sharma S, Adams DR, Otten RA, Heneine W, Hendry RM, McNicholl JM, et al. 2011 High susceptibility to repeated, low-dose, vaginal SHIV exposure late in the luteal phase of the menstrual cycle of pigtail macaques. Journal of Acquired Immune Deficiency Syndromes $\mathbf{5 7}$ 261-264. (doi:10.1097/QAI.0b013e318220ebd3)

Wald A \& Link K 2002 Risk of human immunodeficiency virus infection in herpes simplex virus type 2-seropositive persons: a meta-analysis. Journal of Infectious Diseases 185 45-52. (doi:10.1086/338231)

Wang X, Viswanath R, Zhao J, Tang S \& Hewlett I 2010 Changes in the level of apoptosis-related proteins in Jurkat cells infected with HIV-1 versus HIV-2. Molecular and Cellular Biochemistry 337 175-183. (doi:10.1007/s11010-009-0297-9)

Wang X, Gao Y, Tan J, Devadas K, Ragupathy V, Takeda K, Zhao J \& Hewlett I 2012 HIV-1 and HIV-2 infections induce autophagy in Jurkat and CD4+ T cells. Cellular Signalling 24 1414-1419. (doi:10.1016/j.cellsig.2012.02.016)

Yin P, Lin Z, Cheng YH, Marsh EE, Utsunomiya H, Ishikawa H, Xue Q Reierstad S, Innes J, Thung S, et al. 2007 Progesterone receptor regulates Bcl-2 gene expression through direct binding to its promoter region in uterine leiomyoma cells. Journal of Clinical Endocrinology and Metabolism 92 4459-4466. (doi:10.1210/jc.2007-0725)

Zhang M, Huang Q, Huang Y, Wood O, Yuan W, Chancey C, Daniel S, Rios M, Hewlett I, Clouse KA, et al. 2008 beta-estradiol attenuates the anti-HIV-1 efficacy of Stavudine (D4T) in primary PBL. Retrovirology 5 82. (doi:10.1186/1742-4690-5-82)

Received in final form 10 August 2016

Accepted 18 August 2016

Accepted Preprint published online 18 August 2016

Published by Bioscientifica Ltd. http://jme.endocrinology-journals.org

DOI: 10.1530/JME-16-0138
๑ 2016 Society for Endocrinology Printed in Great Britain 